\title{
Shareholder Litigation and Corporate Disclosure: Evidence from Derivative Lawsuits*
}

\section{Thomas Bourveau $^{\dagger} \quad$ Yun Lou $^{\ddagger} \quad$ Rencheng Wang ${ }^{\S}$}

\begin{abstract}
Using the staggered adoption of universal demand (UD) laws in the United States, we study the effect of shareholder litigation risk on corporate disclosure. We find that disclosure significantly increases after UD laws make it more difficult to file derivative lawsuits. Specifically, firms issue more earnings forecasts and voluntary 8-K filings, and increase the length of management discussion and analysis (MD\&A) in their 10$\mathrm{K}$ filings. We further assess the direct and indirect channels through which UD laws affect firms' disclosure policies. We find that the effect of UD laws on corporate disclosure is driven by firms facing relatively higher ex ante derivative litigation risk and higher operating uncertainty, as well as firms for which shareholder litigation is a more important mechanism to discipline managers.
\end{abstract}

Keywords: Corporate Governance, Derivative Lawsuits, Corporate Disclosure, Shareholder Litigation, Universal Demand Laws

\section{JEL Classification: M41, G10}

\footnotetext{
*Accepted by Philip Berger. We are grateful for the constructive comments and suggestions from an anonymous reviewer. We appreciate the feedback from Pat Akey, Mary Billings (discussant), Francois Brochet, Brian Cadman, Xia Chen, Qiang Cheng, Ed deHaan, Fabrizio Ferri, Denis Gromb, Rachel Hayes, Gilles Hilary, Justin Hopkins, Charles Hsu, Ian Gow, Bin Ke, Christian Leuz, Xi Li, Yinghua Li, Hai Lu, Russell Lundholm, Greg Miller, Clemens Otto, Sugata Roychowdhury, Jordan Schoenfeld, Nemit Shroff, Douglas Skinner, Florin Vasvari, Holly Yang, Liandong Zhang and seminar participants at HEC Paris, National Singapore University, Nanyang Technological University, Singapore Management University, Tilburg University, the 2016 Utah Winter Accounting Conference, and the 2016 European Accounting Association Annual Congress. We thank Bill McDonald and Stephen Brown for sharing the data on firms' historical states of incorporation and MD\&A sections in 10-K filings with us. We also thank Zhiyang Li for his excellent research assistance on 8-K filings. All errors are our own.

${ }^{\dagger}$ Hong Kong University of Science and Technology - actb@ust.hk

‡Singapore Management University - yunlou@smu.edu.sg

$\S$ University of Melbourne - rencheng.wang@unimelb.edu.au
}

This is the author manuscript accepted for publication and has undergone full peer review but has not been through the copyediting, typesetting, pagination and proofreading process, which may lead to differences between this version and the Version of Record. Please cite this article as doi: $10.1111 /$ joar.12191 


\section{Introduction}

Corporate governance is a nexus of mechanisms to ensure that managers' interests are aligned with those of shareholders (Jensen [1993], Shleifer and Vishny [1997]). Prior literature shows that lawsuits brought by shareholders play an important role in reducing agency conflicts between managers and shareholders (e.g., Cheng et al. [2010]). After all, shareholders can effectively discipline managers only if they pose a credible threat to managers. Shareholders also require timely and reliable disclosure to efficiently monitor managers (Armstrong et al. [2010]). But how exactly shareholder litigation interacts with corporate disclosure to align managers' and shareholders' interests is not entirely understood (Armstrong et al. [2010]). In this paper, we exploit unexpected regulatory changes that affect shareholders' ability to pursue derivative lawsuits to examine the effect of shareholder litigation on a firm's disclosure decisions. ${ }^{1}$

Specifically, we use the staggered adoption of universal demand (UD) laws across different U.S. states as a source of exogenous variation in the threat of derivative lawsuits to identify the causal effect of changes to shareholder litigation risk on corporate disclosure. UD laws require derivative plaintiffs (i.e., shareholders) to make a demand on a firm's board of directors before filing a derivative lawsuit. The board of directors usually refuses this request since most of the members are named as defendants in the lawsuit. Hence, the adoption of UD laws imposes a significant hurdle for shareholders to file derivative lawsuits. Consequently, the litigation risk pertaining to derivative lawsuits has decreased significantly following the passage of UD laws (Appel [2016]).

Derivative lawsuits are lawsuits brought by shareholders in the name of the firm to sue its management. They are a mechanism to enforce managers' fiduciary duties and force managers to compensate the firm for the damage they allegedly caused. The settlements

\footnotetext{
${ }^{1}$ An important difference between our study and the prior literature on the relation between shareholder litigation and corporate disclosure (e.g., Johnson et al. [2001]) is that our study does not exclusively rely on the assumption that corporate disclosure can trigger shareholder litigation. We argue that shareholder litigation can also influence corporate disclosure indirectly through its role as a governance tool.
}

This article is protected by copyright. All rights reserved. 
of derivative lawsuits often come at significant costs to managers. First, derivative lawsuits may lead to direct pecuniary costs (Erickson [2010]) and reputational penalties (Brochet and Srinivasan [2014]). Second, the settlements of derivative lawsuits often contain corporate governance reforms that reduce managerial entrenchment. For example, Ferris et al. [2007] find that the settlements of derivative lawsuits are followed by an increase in the number of independent directors. Thus, derivative lawsuits not only have a direct impact on managers but also have an indirect effect on the firm's corporate governance structure.

We hypothesize that the decrease in the derivative litigation risk can affect firms' disclosure policies directly through changes in expected costs and benefits related to potential derivative lawsuits and indirectly via the role of derivative lawsuits as a corporate governance tool. First, the change in expected litigation costs such as monetary payoffs and reputational damage can alter managers' incentives to disclose information. Specifically, managers trade off costs and benefits when deciding whether to disclose private information. On the one hand, managers may voluntarily disclose bad news because such disclosures may prevent litigation in cases of large stock price declines (Skinner [1994]). If so, when the threat of derivative lawsuits decreases, the marginal benefit of disclosing bad news also decreases. As a result, managers may opportunistically reduce bad news disclosure. On the other hand, managers may avoid voluntarily disclosing forward-looking information because such disclosures may invite future shareholder lawsuits (Johnson et al. [2001], Rogers and Stocken [2005]). Hence, when the decreased derivative litigation risk reduces the marginal cost of such disclosures, managers may be more willing to disclose.

Second, the reduction in the threat of derivative lawsuits can also affect disclosure policies indirectly through the role of derivative lawsuits as a corporate governance mechanism. Appel [2016] argues that derivative lawsuits play an important role in disciplining managers. He shows that a decrease in the derivative litigation risk can weaken firms' corporate governance quality and lead to an increase in governance provisions (e.g., classified boards) that entrench managers. This creates two opposing effects on firms' disclosure policies. On 
the one hand, the decrease in the derivative lawsuit risk can reduce shareholders' ability to discipline managers using shareholder litigation rights, which in turn increases shareholders' demand for more information to monitor managers. For example, for firms where derivative lawsuits are a more important governance tool for shareholders to discipline managers, the demand for corporate disclosure should be stronger following the decrease in the derivative litigation risk. On the other hand, the reduction in the threat of derivative lawsuits can lead to more managerial entrenchment, which may affect managers' incentives for disclosure. For example, entrenched managers may want to stay opaque and share less information with the capital markets in order to enjoy private benefits (e.g., Ferreira and Laux [2007]).

Therefore, it is unclear ex ante whether and how the decrease in the derivative lawsuit risk can affect firms' disclosure policies. Our main empirical finding is consistent with an increase in corporate disclosure in response to a reduction in the threat of derivative lawsuits due to the passage of UD laws. Specifically, we first document that firms significantly increase the frequency of management earnings forecasts following the adoption of UD laws. Attesting to the economic importance of earnings forecasts, Beyer et al. [2010] state that $16 \%$ of stock return variance is explained by guidance disclosure (which is more than all SEC filings and press releases combined). In addition, we recognize that corporate disclosure comes in many forms, and therefore we complement the frequency of management earnings forecasts with the length of management discussion and analysis (MD\&A) in 10-K filings and the frequency of voluntary 8-K filings. We find that firms also increase the length of MD\&A and the frequency of voluntary 8-K filings after the adoption of UD laws.

We further attempt to distinguish among the direct and indirect channels through which the increase in the disclosure operates. We find evidence that the effect of UD laws on corporate disclosure is driven by firms that face relatively higher ex ante derivative lawsuit risk. In particular, firms operating in relatively more uncertain environments significantly increase their disclosure because it is harder for them to predict future outcomes ex ante, and thus they were more exposed to lawsuits related to disclosures that could be viewed as misleading 
ex post prior to the adoption of UD laws. These results are consistent with the argument that the change in expected litigation costs affects managers' incentives to disclose. Furthermore, firms that have dispersed institutional ownership also exhibit significant increases in corporate disclosure, which suggests that derivative lawsuits are particularly important when alternative corporate governance mechanisms are weak. Taken together, our results indicate that UD laws affect corporate disclosure not only directly through the change in expected litigation costs but also indirectly via the reduced role of derivative lawsuits as a governance tool.

We then investigate whether UD laws increase managers' willingness to share more information with shareholders or lead to more opportunistic disclosure behavior. Such an investigation is important because it helps us distinguish whether shareholder litigation risk reduces the overall disclosure level or disciplines managers' opportunistic disclosure behavior. If shareholder litigation risk discourages the overall amount of information disclosed, the decrease in the litigation risk provides potential benefits to the capital markets in terms of more information sharing regardless of the nature of the news (e.g., bad versus good news). Our findings show that UD laws increase the disclosure frequencies of both good and bad news, and both optimistic and pessimistic news, in a similar way. Moreover, the precision and quality of disclosed information also improve following the adoption of UD laws. Specifically, the width of earnings forecast errors becomes smaller and the level of discretionary accruals decreases. Overall, UD laws seem to incentivize managers to share more and better-quality information with shareholders rather than exercise more opportunistic disclosure behavior.

Our study makes several contributions to the literature. First, by exploiting the passage of UD laws as an exogenous change in shareholder litigation risk, we provide cleaner evidence on the causal relationship between shareholder litigation and corporate disclosure. Many of the prior studies that examine the relation between shareholder litigation risk and corporate disclosure are subject to significant measurement errors and endogeneity concerns. For example, ex ante firm characteristics, industry membership, and ex post filings of class action 
lawsuits have been used in the literature to proxy for shareholder litigation risk (Francis et al. [1994], Field et al. [2005], Kim and Skinner [2012]). These measures are either endogenously determined by firm fundamentals or confounded by industry characteristics, both of which cast doubt on the credibility of the findings built on them. Because we use the staggered adoption of UD laws as an exogenous shock to the litigation risk, our results are less susceptible to the measurement errors and endogeneity concerns that are widespread in the existing literature.

Second, our study also broadens the understanding of the role of shareholder litigation in corporate disclosure. There is a significant body of accounting literature on the direct role of shareholder litigation in shaping corporate disclosure policies (e.g., Skinner [1994; 1997], Johnson et al. [2001], Field et al. [2005]). These studies focus on whether expected litigation risk deters managers from disclosing forward-looking information or encourages them to disclose more information. We add to this literature by taking into account the indirect role of shareholder litigation risk in facilitating corporate disclosure via corporate governance. We thereby provide comprehensive evidence on the channels through which shareholder litigation affects corporate disclosure.

Finally, our study is closely related to the growing literature on the role of shareholder litigation in corporate decisions (e.g., Cheng et al. [2010], Chu and Zhao [2015], Appel [2016]). Using the enactment of UD laws as an exogenous shock to shareholder litigation, Appel [2016] studies its effect on firms' governance, compensation, and financing policies. We add to this literature by showing that UD laws also affect corporate disclosure. Furthermore, we demonstrate that there are also benefits associated with weakened shareholder litigation: increased disclosure provided by firms.

The rest of the paper is organized as follows. Section 2 provides the institutional background. In Section 3, we develop our hypotheses. We describe the research design and variable measurement in Section 4. We present the results in Section 5. We provide some additional analyses in Section 6. We conclude in Section 7. 


\section{Institutional Background}

Shareholder litigation plays an important role in enforcing managers' fiduciary duties and securities laws in the United States. For instance, derivative lawsuits are the procedural mechanism to implement state fiduciary duty laws, while securities class actions are the mechanism to enforce federal securities laws. The 1995 Private Securities Litigation Reform Act (PSLRA) limits shareholders' ability to file class action lawsuits. However, it does not affect the conditions for filing derivative lawsuits. Consequently, many shareholders have diverted their efforts from class action lawsuits to derivative lawsuits in the post-PSLRA years (Erickson [2010]).

A derivative lawsuit allows shareholders, acting on behalf of the firm, to sue managers for their alleged wrongdoings. Examples of wrongdoing include managers' illegal activities, mishandling of information, or self-dealing. In a derivative lawsuit, the firm is the actual plaintiff, and the shareholders who initiate the lawsuit are the derivative plaintiffs. The objective of the derivative lawsuit is to enforce managers' fiduciary duties and force managers to compensate the firm for the damage they allegedly caused.

A significant number of derivative lawsuits are settled, and these settlements can involve financial remuneration and/or corporate governance reforms (Erickson [2010]). Although directors and officers (D\&O) liability insurance can cover the monetary losses of derivative lawsuits, D\&O insurance does not cover wrongdoings that involve managers' dishonesty, intentional misconduct, or breaches in which managers have reaped a personal gain (Cox [1999]). Hence, D\&O insurance does not completely shield managers from financial liabilities resulting from derivative lawsuits. Even if managers do not suffer from any financial penalties related to derivative lawsuits, their reputations can be damaged if they are implicated in lawsuits (Cox [1999]). A damaged reputation can in turn negatively affect managers' future career prospects (Strahan [1998], Brochet and Srinivasan [2014]). Furthermore, derivative lawsuits can also be costly to the firms since the lawsuits distract managers' attention and potentially increase the premiums on D\&O insurance.

This article is protected by copyright. All rights reserved. 
Moreover, the resolution of derivative lawsuits often involves stringent corporate governance reforms. Erickson [2010] finds that more than $80 \%$ of the settlements of derivative lawsuits include reforms of governance practices. These settlements require managers to appoint or enhance the duties of a lead independent director, to attend a certain percentage of board, committee, or shareholder meetings, or to adopt a clawback provision. As a consequence, the corporate governance reforms that come with derivative lawsuits can limit managers' ability to entrench themselves in the firm and reduce their flexibility in making corporate decisions. Consistent with these arguments, Ferris et al. [2007] find that derivative lawsuits are not frivolous and are associated with significant improvements in corporate governance.

Nevertheless, there is a significant procedural hurdle in filing a derivative lawsuit. Specifically, prior to the filing of a derivative lawsuit, the shareholders of the firm must first demand that the board of directors bring legal action against the wrongdoers. The demand requirement stems from the "cardinal precept" of corporate law that directors, not shareholders, manage the affairs of a firm (Erickson [2010]). Therefore, it should be the directors who decide whether to initiate the lawsuit for the firm. However, in practice, the majority of board members (including the $\mathrm{CEO}$ ) are often named as defendants in derivative lawsuits. Naturally, the directors rarely want to approve the demand. If the board of directors disapproves the demand, a judge typically follows the board's decision and dismisses the lawsuit.

To mitigate the board of directors' conflict of interest arising from the demand requirement, many states follow the "demand futility" doctrine. The demand futility doctrine allows shareholders to bypass the demand requirement and file a derivative lawsuit without the directors' approval. To do so, shareholders need to prove that the majority of the directors cannot impartially judge the necessity of initiating a derivative lawsuit. The demand futility doctrine has its own problems. In particular, it causes inefficiency in the legal procedure as the doctrine provides strong incentives for plaintiffs to focus on demonstrating the demand futility rather than the director and officers' breach of fiduciary duties (Swanson [1993]). 
To overcome the shortcomings of the demand futility doctrine, 23 U.S. states adopted universal demand laws between 1989 and 2005. These laws require shareholders to make a demand in every derivative lawsuit. The demand requirement is determined by the firm's state of incorporation regardless of whether the derivative lawsuit is filed in a state or federal court. ${ }^{2}$ The adoption of UD laws thus restores the effectiveness of the demand requirement and helps directors regain control of derivative lawsuits. As a consequence, fewer derivative lawsuits are filed and the litigation risk pertaining to derivative lawsuits is significantly reduced in the states that adopted the UD laws. For example, Appel [2016] finds that the passage of UD laws leads to a one-third decrease in the filing of derivative lawsuits.

\section{Hypothesis Development}

Shareholder litigation can affect corporate disclosure through the direct role of litigation risk and indirectly via the role of shareholder litigation as a governance tool.

Prior studies have examined the direct role of litigation risk in shaping corporate disclosure policies. For example, Skinner [1994] argues that managers disclose bad news in a timelier manner to pre-empt shareholder litigation. Kasznik and Lev [1995] find consistent evidence that firms disclose earnings warnings to avoid large negative earnings news that may lead to shareholder lawsuits. Recent studies (e.g., Field et al. [2005], Billings and Cedergren [2015]) also show that early disclosure of earnings-related bad news can reduce litigation risk. This line of literature suggests that firms are more likely to disclose news, particularly bad news, when they face high litigation risk. Since UD laws reduce the litigation risk (and thus the marginal benefit of disclosing bad news), we may expect to observe fewer disclosures, in particular disclosures of bad news, following the passage of UD laws.

However, there is also empirical evidence showing that more disclosures do not necessarily protect managers or firms from being sued. For instance, Francis et al. [1994] find that more

\footnotetext{
${ }^{2}$ In Kamen v. Kemper Financial Services Inc.(1991), the Supreme Court ruled that for derivative lawsuits filed in federal courts, whether a demand requirement needs to be made or not should be determined by the laws adopted by the state where the firm is incorporated.
} 
voluntary disclosures are associated with a higher incidence of shareholder lawsuits. In fact, after being sued for disclosures made in good faith, managers revise their belief that pre-emptive disclosures can deter lawsuits, and in turn they reduce the level of voluntary disclosures (Rogers and Van Buskirk [2009]). Furthermore, Johnson et al. [2001] provide direct evidence that firms are more willing to make good news disclosures when ex ante class action litigation risk decreases. These findings are consistent with the argument that managers are afraid of making forward-looking disclosures because such disclosures can bring future shareholder lawsuits. In particular, they tend to avoid good news disclosures that may turn out to be inaccurate or wrong ex post. This is because investors who lose money after a decrease in share value can bring lawsuits against management for issuing an optimistic forecast or failing to issue an earnings warning (Cheng and Lo [2006]). These lawsuits can impose significant costs on the managers and firms, such as reputational damage (Srinivasan [2005], Brochet and Srinivasan [2014]), distracted attention, and increased D\&O insurance premiums. Hence, if UD laws reduce the likelihood of being sued and the costs conditional on being sued in derivative lawsuits, firms will also be more willing to share information with shareholders. In particular, firms with higher ex ante derivative litigation risk or firms that are more concerned about potential lawsuits related to forward-looking disclosures should benefit more from a reduction in the litigation risk. For example, it is generally much harder for firms that operate in more uncertain operating environments to predict future outcomes. Hence, prior to the adoption of UD laws, these firms may be more worried about being sued for disclosures that could be viewed as misleading ex post. The adoption of UD laws alleviates their concerns about potential lawsuits associated with such disclosures, and in turn they disclose more information to the public.

Moreover, managers' incentives for disclosure can also be indirectly affected by the weakened role of shareholder litigation as a governance mechanism following the passage of UD laws.

First, the adoption of UD laws reduces shareholders' ability to discipline managers via 
shareholder litigation, and such litigation is an integral part of a firm's corporate governance structure (Ferris et al. [2007], Cheng et al. [2010]). In order to restore the level of external monitoring, shareholders may seek other governance mechanisms, such as more corporate disclosure, to discipline managers. If so, the increase in corporate disclosure should be greater for firms where derivatives lawsuits were an important governance tool prior to the adoption of UD laws. For example, firms with dispersed ownership were subject to weaker shareholder monitoring because shareholder rights such as voting and selling can be effectively exercised only via concentrated ownership (Thompson [1999], Appel [2016]). As a result, dispersed shareholders may resort to their ability to bring lawsuits to discipline managers (Crane and Koch [2017]). Hence, if UD laws reduce the role of derivative lawsuits as a governance mechanism, the demand for disclosure to monitor managers should also be higher for firms with dispersed ownership.

However, UD laws may also lead to more managerial entrenchment and increase the agency costs between managers and shareholders, thereby negatively impacting corporate disclosure. Appel [2016] shows that managers increase the anti-takeover provisions after the adoption of UD laws. The resulting increase in managerial entrenchment can in turn alter managers' incentives to disclose information. Specifically, entrenched managers may prefer to share less information with the capital markets because a more transparent information environment can reduce their private benefits of control (Fu and Liu [2007]). In contrast, opaqueness can help managers expropriate wealth from shareholders (Jin and Myers [2006], Ferreira and Laux [2007]). Furthermore, Bertrand and Mullainathan [2003] argue that when managers are insulated from takeovers, they enjoy the quiet life and avoid making cognitively difficult decisions. Consequently, managers may provide fewer disclosures to the public following the passage of UD laws. 


\section{Research Design and Sample Construction}

\subsection{Research Design}

We use the staggered adoption of UD laws as a source of plausibly exogenous variation to shareholder litigation and examine the impact of UD laws on corporate disclosure. Specifically, we estimate various ordinary least squares (OLS) specifications of the following generalized difference-in-differences model:

$$
\text { Disclosure }_{i s t}=\beta_{0}+\beta_{1} U D \text { Law }_{s t}+\text { Controls }_{i s t}+\alpha_{i}+\theta_{s^{\prime} t}+\gamma_{f t}+\epsilon_{i s t}
$$

where $i, s, s^{\prime}, f$ and $t$ denote firm, state of incorporation, state of location (headquarters), industry and year, respectively. In the main analysis, we use three different voluntary disclosure measures detailed in the next sub-section as dependent variables. We focus on voluntary disclosure in the main analysis for two reasons: First, managers have more discretion over voluntary disclosures than mandatory financial reporting, which allows managers' changes in incentives to come into play. Second, the majority of the prior literature on the relation between litigation risk and corporate disclosure tends to use discretionary disclosures (e.g., Kasznik and Lev [1995], Johnson et al. [2001]). Hence, to make our inferences comparable to those of prior literature, we primarily study managers' decisions to voluntarily disclose information. However, in supplemental analyses, we also examine the effect of UD laws on the quality of mandatory financial reporting.

The independent variable of interest, UD Law, is an indicator variable that takes the value of one if a state has a UD law in place in year $t$. We follow Appel [2016] and define whether a firm is subject to a UD law based on its state of incorporation. Unfortunately, Compustat provides information only for the most recent state of incorporation, which can introduce measurement errors into the assignment of treatment versus control firms. To overcome this problem, we use the historical state of incorporation provided by Bill McDonald to identify 
whether a firm is incorporated in a state with a UD law in a given year. ${ }^{3}$

In our baseline specification of Equation (1), we include firm fixed effects $\left(\alpha_{i}\right)$ and state of location-year fixed effects $\left(\theta_{s^{\prime}}\right) .{ }^{4}$ Firm fixed effects account for time-invariant characteristics, while state-year fixed effects control for unobserved heterogeneity that varies locally across time (e.g., local economic conditions). This research design essentially represents a differencein-differences approach in which firms incorporated in states that do not have a UD law in place in a given year serve as the control group for firms incorporated in states that have the law in place in that year. The coefficient $\beta_{1}$ is our difference-in-differences estimate, which captures the average effect of UD laws for the treatment group relative to the control group. We also follow Bertrand and Mullainathan [2003] and augment our model with industry-year fixed effects at the Fama-French 30 industries level $\left(\gamma_{f t}\right)$. The industry-year fixed effects allow us to control for unobservable factors that vary at the industry-year level (e.g., investment opportunities).

In the above baseline specifications, we do not include any time-varying firm-level control variables because such variables may lead to inconsistent estimates (Gormley and Matsa [2014]). Instead, we rely on a set of fixed effects to eliminate unobserved time-invariant factors within firms and unobserved heterogeneity that varies across states and industries. However, we estimate additional specifications where we also control for a set of variables that are known to be primary determinants of firms' disclosure decisions. Specifically, we follow prior literature and include a set of firm characteristics such as institutional ownership (Institutional ownership) (Ajinkya et al. [2005], Karamanou and Vafeas [2005]), firm size (Firm size) (Lang and Lundholm [1993], Kasznik and Lev [1995], Frankel et al. [1995]), and book-to market ratio (Book-to-market) to capture firms' incentives for communicating

\footnotetext{
${ }^{3}$ Bill McDonald obtained the historical state of incorporation by parsing firms' 10-K filings on the Electronic Data Gathering, Analysis, and Retrieval (EDGAR) system from the U.S. Securities and Exchange Commission (SEC). If the historical state of incorporation is not available on his website, we use the current state of incorporation from Compustat.

${ }^{4}$ For simplicity, we refer to the construction state of location-year fixed effects as state-year fixed effects from now on. Note that we cannot include state of incorporation-year fixed effects in the regressions, as such fixed effects would, by definition, be perfectly correlated with our treatment variable, UD Law.
} 
private information to the public (Waymire [1985], Graham et al. [2005]). We also control for return on assets (ROA), stock return (Stock return), earnings volatility (Earnings volatility), and a loss indicator (Loss) to take into account the influence of firm performance (e.g., Miller [2002], Lennox and Park [2006], Chen et al. [2011]). Further, to differentiate the effect of derivative litigation risk from that of class action litigation risk, we include a continuous variable, Class action litigation risk, estimated using the procedure developed by Kim and Skinner [2012]. ${ }^{5}$

Since UD laws are implemented at the state of incorporation level, we cluster standard errors by the state of incorporation throughout all specifications. ${ }^{6}$ This conservative clustering method accounts for potential time-varying correlations in omitted variables that may affect different firms within the same state (Bertrand et al. [2004]). All continuous variables are winsorized at the $1 \%$ and $99 \%$ levels. Appendix $\mathrm{C}$ provides detailed definitions for all our variables.

\subsection{Sample Construction}

We start the sample with firms in the Compustat-CRSP merged database for 1995 2007. We then limit the sample to observations for which we are able to construct the control variables described in Section 4.1. To construct these control variables, we obtain financial information from Compustat, institutional ownership from Thomson Reuters, analyst forecasts from the Institutional Brokers' Estimate System (I/B/E/S), and stock price from the Center for Research in Security Prices (CRSP). We drop firms incorporated in foreign countries. Finally, we follow Appel [2016] and exclude firms that changed their state of incorporation during our sample period.

\footnotetext{
${ }^{5}$ Our results are robust to controlling for analyst following (Skinner [1997], Graham et al. [2005]), analyst forecast bias (Lennox and Park [2006]), analyst forecast dispersion (Cotter et al. [2006]), financial distress (Frost [1997]), external financing (Frankel et al. [1995]), industry competition (Newman and Sansing [1993]), insider trading (Cheng and Lo [2006]), stock return volatility (Ali et al. [2004]), and the value-relevance of earnings (Matsumoto [2002], Hutton [2005]).

${ }^{6}$ Our results are robust to using alternative clustering methods such as bootstrapping. We report these robustness checks in Appendix A4.
} 
We define our main dependent variable, FreqMF, as the natural logarithm of one plus the number of management earnings forecasts issued during a given year. We use management earnings forecast as our main corporate disclosure measure for two reasons. First, management earnings forecast is the voluntary disclosure tool that explains the largest fraction of stock return variance (Beyer et al. [2010]). In addition, Brown et al. [2015] also surveyed sell-side analysts who acknowledged that management earnings guidance constitutes a very useful element in establishing their own earnings forecasts and stock recommendations. In fact, analysts indicated that management earnings guidance is a more useful source of information than firms' recent earnings performance and 10-K/Q filings. Finally, management earnings forecast is the measure most commonly used in studies pertaining to managers' corporate disclosure choices (e.g., Shroff et al. [2013], Balakrishnan et al. [2014a], Gow et al. [2016], Schoenfeld [2017]).

We obtain all managerial annual and quarterly earnings per share (EPS) estimates from the Company Issued Guidance (CIG) in the First Call Historical Database and restrict our time period to $1998-2007 .^{7}$ This sample period allows us to identify management forecasts relatively accurately and mitigates the potential coverage issues of missing data in the earlier years of the First Call database (Chuk et al. [2013]). We include both qualitative and quantitative earnings forecasts. ${ }^{8}$ Our final management forecast sample consists of 30,873 firm-year observations.

Second, we follow Lo [2014] and use the length of the Management's Discussion and Analysis (MD\&A) sections in 10-K filings as a complementary proxy for the level of corporate disclosure. While the inclusion of an MD\&A section itself is mandatory, the content is largely at the discretion of the manager (Li [2008], Bloomfield [2008], Loughran and McDonald [2014]). Recent studies also show that a firm's disclosure in MD\&A has incremental explanatory power in predicting future performance (Feldman et al. [2010], Li [2010]). This

\footnotetext{
${ }^{7}$ We end the sample at 2007 , which is two years after the last states adopted the UD laws. This also helps us to avoid the confounding effect of the recent financial crisis.

${ }^{8}$ Throughout the paper, we use the terms earnings guidance, earnings forecast, earnings estimate and management forecast interchangeably.
} 
evidence suggests that the length of MD\&A is a reasonable proxy for the level of valuerelevant voluntary disclosure (Leuz and Schrand [2009]).

We obtain the length of the MD\&A sections in 10-K filings from Brown and Tucker [2011]. Brown and Tucker [2011] retrieve 10-K filings from EDGAR and extract MD\&A from Item 7 in each filing. We define the variable LengthMDA as the natural logarithm of one plus the number of words in the MD\&A section of $10-\mathrm{K}$ filings in a given year. ${ }^{9}$ Our final MD\&A sample consists of 19,413 firm-year observations.

Third, we also complement our main disclosure measure with the frequency of 8-K filings. Prior studies such as Carter and Soo [1999] and Lerman and Livnat [2010] show that 8-K filings produce information relevant to financial markets and contribute to the price formation process. In addition, an important feature of 8-K filings is that, although the majority of the items in the 8-K filings are mandatory, the SEC allows substantial managerial discretion in filing decisions for several items. Consequently, recent studies have used 8-Ks as a measure of corporate disclosure (Balakrishnan et al. [2014b], Boone and White [2015], Seo [2016], Schoenfeld [2017]).

We obtain information on 8-K filings from EDGAR and create two measures: Freq Vol8k and FreqMansk. We define FreqVolsk as the natural logarithm of one plus the number of voluntary 8-K filings in a given fiscal year. Previous studies argue that there are several items over which managers have pronounced discretion (Lerman and Livnat [2010], Seo [2016]). We follow Cooper et al. [2016] and define 8-K filings that contain items 5, 9, and 12 in the pre-2004 period, and those that contain items 2.02, 7.01, and 8.01 in the post-2004 period, as voluntary filings. ${ }^{10}$ Conversely, we define the variable FreqMansk as the natural logarithm of one plus the number of other (i.e., non-voluntary) 8-K filings in a given fiscal year. We use the FreqMan8k variable as a placebo test, for which we do not expect to find changes

\footnotetext{
${ }^{9}$ We acknowledge that longer and more complex text may obfuscate rather than inform investors (e.g., Li [2008], Bloomfield [2008], Loughran and McDonald [2014]). Thus, we consider the length of the MD\&A filing as a complementary measure for the level of voluntary disclosure.

${ }^{10}$ The change of regulation pertaining to 8-K filings happened in 2004 and led to the change in the labelling of items in the post-2004 period.
} 
or weaker changes in disclosure after the adoption of UD laws. Such a placebo test ensures that our results primarily represent changes to managers' incentives for voluntary disclosure. Our final 8-K filing sample consists of 39,055 firm-year observations.

We follow Appel [2016] to designate the state of incorporation and event year pertaining to the passage of UD laws. In Appendix B, we list the years and corresponding states that adopted UD laws. The adoption of UD laws occurred from 1989 to 2005 across 23 U.S. states. The most recent states to adopt UD laws are Rhode Island and South Dakota, which passed the laws in 2005. Since our main disclosure variable, FreqMF, is available only starting from 1998, we estimate our difference-in-differences coefficient using the last five adopting states. However, we complement the earnings forecast measure with the two other measures (LengthMDA and FreqVolsk) that we are able to construct starting from 1995. These two measures allow us to estimate the coefficient of interest using variation in the litigation regime of the last 13 adopting states. In Table 1, we report the number of observations for the states that are eventually in our treatment group during our sample period.

Panel A of Table 2 reports the summary statistics. The mean value of UD Law is 0.169 , which implies that $16.9 \%$ of firm-years in our sample correspond to observations with a UD law in place. ${ }^{11}$ Appel [2016] finds that in the pre-treatment period, observations from the treatment and control group do not differ economically or statistically in business fundamentals and governance characteristics. We follow Appel [2016] and compare the mean value for treatment and control groups at the beginning of our sample period. Specifically, we exclude firm-year observations that were already treated and compare the value for the firms that will receive the treatment during our sample period to those that will remain untreated during the same period. We fail to find that observations from both groups display statistically significant differences along several observable dimensions including institutional ownership, book-to-market ratio, stock performance, likelihood of reporting a loss, and class action litigation risk. We do find, however, that firms in the treatment group are smaller,

\footnotetext{
${ }^{11}$ The percentage of treatment firms in our sample is similar to the $16 \%$ reported in Appel [2016].
} 
display better accounting performance, and have lower earnings volatility than those in the control group. ${ }^{12}$ The univariate differences are reported in Panel B of Table 2.

In terms of disclosure variables, firms in the treatment group disclose less than those in the control group in the pre-treatment period. Specifically, the mean of FreqMF is equal to 0.378 for the treatment group and 0.416 for the control group in the pre-treatment period. For LengthMDA, the mean value is 7.972 (treatment) and 8.444 (control), while it is 0.357 (treatment) and 0.674 (control) for FreqVol8k. Our univariate tests reveal that such differences are statistically significant for the length of MD\&A and frequency of 8-K filings. We address this concern in two ways. First, we directly test in Section 5 whether the changes in corporate disclosure precede the adoption of UD laws. Indeed, the key assumption of a difference-in-differences analysis using plausibly exogenous changes in regulation is not that the observations in the treatment and control group are similar ex ante, but rather that they display a parallel trend before the regulation change (Bertrand et al. [2004], Gow et al. [2016]). Second, we directly examine in Section 6 the exogeneity of the adoption of UD laws by analyzing whether state-level determinants of corporate disclosure explain the changes in the litigation regime.

\section{$5 \quad$ Main Results}

\subsection{UD Laws and Corporate Disclosure}

In this sub-section, we examine whether a plausibly exogenous decrease in shareholders' ability to pursue derivative lawsuits affects firms' propensity to voluntarily provide information to capital markets.

Table 3 presents the results for the impact of UD laws on corporate disclosure using the three voluntary disclosure measures described in Section 4.2. In columns (1), (2), and

\footnotetext{
${ }^{12}$ The observations from our treatment and control groups are not the same as those in Appel [2016] because we start our sample in 1995 or 1998 due to the availability of our disclosure measures, while his sample starts in 1987.
} 
(3), the dependent variable captures the frequency of earnings forecasts. One concern is that including covariates that may be affected by the treatment can undermine the ability to draw causal inferences (Gormley and Matsa [2014], Imbens and Rubin [2015]). Hence, in the first two columns, we do not include any time-varying firm-level covariates. Specifically, in column (1), we include only firm and state-year fixed effects. The coefficient on UD Law is positive and statistically significant at the $1 \%$ level. This result indicates that firms in the treatment group tend to increase the frequency of earnings forecasts after the implementation of UD laws relative to control firms. In column (2), we augment our model with industry-year fixed effects to account for unobservable industry characteristics that vary at a yearly frequency. The magnitude of the coefficient of interest is slightly reduced but remains statistically significant at the $1 \%$ level. Finally, in the third column, we add known determinants of voluntary disclosure to our empirical model, and our coefficient of interest remains stable and statistically significant at the $1 \%$ level. ${ }^{13}$

In columns (4), (5), and (6) of Table 3, we examine the effect of the adoption of UD laws on the length of the MD\&A section in 10-K filings. Across all specifications, the coefficient on UD Law is positive and statistically significant at the $1 \%$ level. This result shows that firms in the treatment group tend to increase the length of their MD\&A section in 10-K filings after the implementation of UD laws, relative to firms from the control group.

In columns (7), (8), and (9) of Table 3, we examine the effect of the adoption of UD laws on the frequency of voluntary 8-K filings over which managers have significant discretion (Lerman and Livnat [2010], Cooper et al. [2016], Seo [2016]). The coefficient estimate is positive and statistically significant at conventional statistical levels for all three specifications. This is evidence that the adoption of UD laws leads to an increase in voluntary disclosure along another dimension of disclosure. Taken together, the results in Table 3 support our prediction that firms respond to the decrease in the derivative litigation risk by providing

\footnotetext{
${ }^{13}$ Note that the coefficients on the control variables have the expected signs. For example, we find that the frequency of earnings forecasts is positively related to institutional ownership, firm size, and operating performance, consistent with Kasznik and Lev [1995], Miller [2002], Ajinkya et al. [2005], and Chen et al. [2011].
} 
more corporate disclosures.

We now discuss the economic magnitudes of our finding using the most conservative specifications in columns (3), (6), and (9). For the main dependent variable, FreqMF, our estimation reveals that the frequency of management earnings forecasts increases by $12.13 \%$, an economically meaningful effect. ${ }^{14}$ Turning to the two complementary disclosure variables, we see that the length of the MD\&A in the $10-\mathrm{K}$ filings increases by $6.67 \%$, while the frequency of voluntary $8-\mathrm{K}$ filings increases by $7.76 \%$. Hence, our difference-in-differences coefficient is fairly stable across the three voluntary disclosure measures. To further gauge the economic magnitude of the effect of UD laws on the level of corporate disclosure, we compare our estimates with those of other studies looking at plausibly exogenous changes in managers' incentives to voluntarily provide information. For example, Schoenfeld [2017] uses indexing as an unexpected increase in institutional ownership, and he reports that a one standard deviation increase in the index fund leads to a $20 \%$ increase in earnings forecasts and 8-K filings. Shroff et al. [2013] examine the change in forecasting behavior around seasoned equity offerings following the 2005 securities offering reform. They find that firms increase their forecasting frequencies by one-third in the pre-offering period after the reform. In summary, our results are economically significant and comparable in magnitude to those from other studies using quasi-natural experimental settings.

There are two potential endogeneity concerns regarding our main results. A first concern is that the assignment of treatment and control groups is not random (Gow et al. [2016]). In particular, some regulatory changes may allow firms to choose whether to adopt a new policy. In our setting, managers do not choose whether or not they receive the treatment after the change in regulation. Indeed, Appel [2016] finds no evidence of a pattern of re-incorporation decisions in response to the adoption of UD laws. Hence, the allocation between treatment

\footnotetext{
${ }^{14}$ We interpret the economic magnitude in terms of the frequency of management earnings forecasts (Fre$q M F$ ). If we estimate the economic significance in terms of the raw number of earnings forecasts, the passage of UD laws leads to a $28.59 \%$ increase in the raw number of earnings forecasts at its sample mean $((\exp (0.1213)-1) *[\exp (0.5997) /(\exp (0.5997)-1)]=0.2859)$.
} 
and control groups does not suffer from a selection problem. ${ }^{15}$

A second concern with the difference-in-differences design is that the change in firm behavior may precede the change in regulation. To address this concern, we follow Bertrand and Mullainathan [2003] and decompose the adoption of UD laws into separate time periods for each state. More specifically, we re-estimate our models from Equation (1) and replace the UD Law dummy by several indicator variables. For example, UD Law (=-1) is an indicator variable that takes the value of one for the year before the adoption of UD laws in a given state. The other dummy variables are defined analogously.

Table 4 reports the corresponding results. We use the same three dependent variables as in Table 3 and report the model with control variables. For each dependent variable, we report our results using our most stringent specification including industry-year fixed effects. In columns (1)-(3), the coefficients on UD Law $(=-1)$ are not statistically different from zero. This result indicates that the increase in disclosure in terms of earnings forecasts, length of the MD\&A section, and voluntary 8-K filings did not occur before the implementation of UD laws. Hence, the parallel trend assumption behind the difference-in-differences research design seems to hold in our setting. In contrast, the coefficient on UD Law $(=0)$ is positive and statistically significant at conventional levels for all three disclosure measures. This suggests that the increase in corporate disclosure started immediately in the adoption year of UD laws. Further, the coefficient on $U D$ Law $(=+1)$ is positive and statistically significant at conventional levels for all three voluntary disclosure measures from columns (1) to (3). Finally, the coefficients on $U D \operatorname{Law}(>=2+)$ are also positive and statistically significant in columns (1)-(3) of Table 4. UD Law $(>=2+)$ is an indicator variable that equals one for the period starting two years after the adoption of a UD law in a given state. This result thus suggests that the effect of UD laws on corporate disclosure is not short-lived. Overall, the results in Table 4 suggest that the increase in corporate disclosure does not precede the passage of UD laws.

\footnotetext{
${ }^{15}$ This rests on the assumption that firms' incorporation decisions were not driven by expected changes in litigation regime.
} 


\subsection{Evidence on the Channels through Which UD Laws Affect Corporate Disclosure}

In the previous sub-section, we provide robust evidence of a causal effect of the decrease in the derivative litigation risk on managers' disclosure decisions. In this sub-section, we further investigate the channels through which the impact of UD laws on corporate disclosure takes place. To do so, we examine whether the influence of UD laws on our three voluntary disclosure measures varies directly with expected litigation costs related to derivative lawsuits and indirectly with the role of shareholder litigation as a governance tool.

There are two empirical challenges for cross-sectional analyses pertaining to the staggered adoption of laws. First, firm/industry characteristics on which cross-sectional analyses are based may be affected by the adoption of laws, which can lead to inconsistent estimates of the treatment effect (Gormley and Matsa [2011]). To mitigate this concern, we use ex ante firm/industry characteristics measured in the year prior to the adoption of UD laws to create subsamples in our cross-sectional analyses.

Second, in a traditional differences-in-differences setting where there is only a single law change event, the treatment and control groups are uniquely defined. However, in the case of staggered adoption of laws across different event years, there is more than one law change event, and a particular observation can serve as a 'control' and 'treatment' for different treatment events. The question of how one can measure the ex ante characteristics for the treatment and control groups then arises. To resolve this problem, we follow Gormley and Matsa [2011] and Appel [2016] and use a cohort-based matching approach. Specifically, for each year in which a UD law was passed, we create a cohort consisting of firms incorporated in the states that adopted the UD law that year and all other firms in states without a UD law. We keep observations from three years before and after the adoption of the law for each cohort. We also ensure that control firms are from states that do not have a UD law throughout the seven-year window. Take the 2001 cohort as an example: the treatment

group includes firms incorporated in Hawaii, the only state that adopted a UD law in 2001; 
the control group consists of firms incorporated in other states without a UD law over the period of 1998-2004. ${ }^{16}$ We then classify firms within each cohort based on the cohort median of the relevant ex ante characteristic (e.g., ex ante derivative lawsuit risk). Finally, we pool together all firm-year observations that fall above the cohort median of the ex ante characteristic across cohorts as one subsample, and those below or equal to the cohort median of the ex ante characteristic as another subsample for comparison.

We begin with our cross-sectional prediction that the effect of UD laws on managers' disclosure decisions should be stronger for firms with high ex ante derivative lawsuit risk. To measure a firm's ex ante derivative lawsuit risk, we estimate the firm's probability of being sued in a derivative lawsuit at the end of the year prior to the adoption of UD laws. Specifically, we follow Kim and Skinner [2012] and estimate the following model:

$$
\begin{aligned}
& \text { Sued }_{i, t-1}=\beta_{0}+\beta_{1} \text { Derivative lawsuit industry }_{f, t-1}+\beta_{2} \log (\text { assets })_{i, t-2} \\
& +\beta_{3} \text { Sales }_{\text {growt }}{ }_{i, t-2}+\beta_{4} \text { Returns }_{i, t-2}+\beta_{5} \text { Return volatility }_{i, t-2} \\
& +\beta_{6} \text { Return skewness }_{i, t-2}+\beta_{7} \text { Turnover }_{i, t-2}+\epsilon
\end{aligned}
$$

where $t$ refers to the year that a UD law is adopted. Sued ${ }_{i, t-1}$ equals one if a firm is sued in a derivative lawsuit during year $t-1$, and zero otherwise. Derivative lawsuit industry $y_{f, t-1}$ takes the value of one if there is a derivative lawsuit during year $t-1$ in the industry to which the firm belongs, and zero otherwise. ${ }^{17}$ Following Kim and Skinner [2012], we measure $\log (\text { assets })_{i, t-2}$ as the natural logarithm of the firm's total assets at the end of year $t-2$ and Sales growth $_{i, t-2}$ as year $t-2$ sales less year $t-3$ sales scaled by beginning-of-year $t-2$ total assets. Furthermore, we include the firm's market-adjusted 12-month stock return

\footnotetext{
${ }^{16}$ Note that the same firm-year observation can fall into the control group in multiple cohorts (i.e., the treatment firms are matched to the control firms with replacement).

${ }^{17} \mathrm{Kim}$ and Skinner [2012] use the litigious industries identified by Francis et al. [1994] to measure the industry-level class action lawsuit risk. Since our objective is to capture the industry-level derivative lawsuit risk, we modify the original Kim and Skinner model by incorporating whether there is a derivative lawsuit in the industry to which the firm belongs.
} 
over year $t-2$ Returns $\left._{i, t-2}\right)$ and the standard deviation (Return volatility R $_{i-2}$ ) as well as skewness (Return skewness $s_{i, t-2}$ ) of the firm's 12-month return over year $t-2$ as explanatory variables. Finally, we add to the model the 12-month trading volume accumulated over year $t-2$ scaled by year $t-2$ outstanding shares $\left(\right.$ Turnover $\left._{i, t-2}\right)$. We then estimate the above model over the sample period of 1994-2007 and use the fitted value of the model as a proxy for the firm's ex ante derivative lawsuit risk prior to the adoption of UD laws.

After obtaining the proxy for the firm's ex ante derivative lawsuit risk, we follow the cohort-based matching approach described above to construct the subsamples. Specifically, we classify the observations within each cohort into those that fall above the median of each cohort's ex ante derivative lawsuit risk and those that fall below or are equal to the cohort median. Finally, we pool all observations across cohorts with above-cohort-median (below/equal-to-cohort-median) derivative lawsuit risk as the subsample with high (low) ex ante derivative lawsuit risk.

In Table 5 Panel A, we compare the disclosure decisions of firms in the high versus low ex ante derivative risk subsamples. In line with our expectation, the coefficient on UD Law is positive and statistically significant at conventional levels in the high derivative lawsuit risk subsample (i.e., columns (1), (3), and (5)). This suggests that following the adoption of UD laws, firms with higher ex ante derivative lawsuit risk significantly increase the frequency of their management forecasts, the length of their MD\&A, and the frequency of their voluntary 8-K filings. In contrast, we find that the effect of UD laws on disclosure is statistically insignificant for firms facing lower ex ante derivative lawsuit risk in columns (2), (4), and (6). Furthermore, Wald tests suggest that the differences across the subsamples of high versus low ex ante derivative lawsuit risk are statistically significant for the frequency of management forecasts and voluntary 8 -K filings at the $1 \%$ level.

We next examine how the effect of UD laws on corporate disclosure varies with the level of operating uncertainty that a firm faces. As mentioned in Section 3, it is generally more difficult for firms that operate in high-uncertainty environments to predict future outcomes. 
Thus, these firms may be more concerned about potential lawsuits related to forward-looking disclosures that can be viewed as misleading ex post. Hence, a decrease in the derivative lawsuit risk should have a stronger effect on the level of disclosure for firms operating in highuncertainty operating environments. To test this prediction, we first calculate the average industry standard deviations of sales growth and return on assets over the past ten years prior to the adoption of UD laws. We then follow the same matching method as above and classify firms into two subsamples: those from industries with high operating uncertainty and those from industries with low operating uncertainty. Specifically, we assign a firm into the subsample of high industry-level operating uncertainty if its average industry standard deviation of sales growth or return on assets is above the cohort median, and we classify a firm into the subsample of low industry-level operating uncertainty if its average industry standard deviations of sales growth and return on assets are below or equal to the cohort median. We use the standard deviations of sales growth and return on assets to capture two different aspects of operating uncertainty. Specifically, the standard deviation of sales growth measures the uncertainty of gross revenue, while the standard deviation of return on assets captures the uncertainty of net profit including fluctuations in operating cost. This approach is similar to that of Schrand and Zechman [2012] and Jia et al. [2014], in which they use multiple aspects to measure CEO overconfidence. ${ }^{18}$

Our estimates are reported in Table 5 Panel B. In columns (1), (3) and (5), we find evidence that firms from industries with high operating uncertainty significantly increase the amount of disclosure after the adoption of UD laws. We fail to document such an increase for firms from industries with low operating uncertainty in columns (2), (4) and (6). Furthermore, Wald tests suggest that the differences between high and low operating uncertainty firms are statistically significant for the frequency of management forecasts at the $1 \%$ level and the length of the MD\&A at the $5 \%$ level. Taken together, these results support our prediction that the effect of UD laws on disclosure is concentrated among firms

\footnotetext{
${ }^{18}$ Our results are robust if we measure operating uncertainty using the average industry-level earnings volatility.
} 
facing high operating uncertainty.

Finally, we analyze whether the effect of UD laws on corporate disclosure varies with firms' institutional ownership structure. As mentioned in Section 3, shareholder litigation is likely to be a more important governance tool for firms with dispersed institutional ownership, as shareholders of such firms tend to rely more heavily on their litigation rights to monitor managers. Hence, if disclosure is used as a substitute for shareholder litigation, the increased difficulty in filing derivative lawsuits after the adoption of UD laws should lead to a more pronounced increase in disclosure for firms with more dispersed shareholders. To test this prediction, we define institutional ownership dispersion as minus one times the sum of the squares of the percentage of individual institutional ownership for a firm over the year prior to the adoption of UD laws and again follow the cohort-based matching approach described above. We compare the subsamples of firm-year observations with above-cohortmedian institutional ownership dispersion (high institutional ownership dispersion) versus those with below- or equal-to-cohort-median institutional ownership dispersion (low institutional ownership dispersion).

The corresponding results are reported in Table 5 Panel C. In columns (1), (3) and (5), our estimates reveal that, in line with our prediction, firms with more dispersed ownership significantly increase their amount of disclosure after the adoption of UD laws. However, the results are statistically insignificant for firms with less dispersed ownership (see columns (2), (4) and (6)). Furthermore, Wald tests suggest that the differences between firms with high and low institutional ownership dispersion are statistically significant for the frequency of management forecasts and the length of the MD\&A at the $1 \%$ level, and for the frequency of voluntary 8 -K filings at the $10 \%$ level. ${ }^{19}$

\footnotetext{
${ }^{19}$ In terms of the economic importance of the direct and indirect channels, if we focus on our main disclosure measure (i.e., the frequency of management forecasts), it seems that the indirect channel (i.e., institutional ownership dispersion) is the most important channel. Specifically, the coefficient on UD Law is larger in column (1) of Table 5 Panel C than in column (1) of Table 5 Panels A and B.
} 


\subsection{Overall Disclosure Level vs. Opportunistic Disclosure Behav- ior}

So far, we have shown that UD laws lead to an increase in corporate disclosure. However, we have been silent on the nature of this change. For example, we do not know whether the decrease in the derivative litigation risk affects the overall disclosure level or managers' opportunistic disclosure behavior. Such an investigation can further shed light on how exactly shareholder litigation facilitates or deters corporate disclosure and whether the change in the litigation regime provides benefits to the capital markets. If high shareholder litigation risk reduces managers' willingness to share information, the switch to a low litigation risk regime helps investors obtain more information. Thus, we should expect the positive effect of UD laws to hold for both good and bad news disclosures, and both optimistic and pessimistic disclosures.

To understand the nature of the increase in corporate disclosure following the passage of UD laws, we begin with the analysis of the impact of UD laws on various management forecast properties in Table 6 . We first decompose earnings forecasts into good news and bad news forecasts. Good and bad news forecasts are defined relative to the analyst consensus estimates prior to the management earnings forecasts. If high shareholder litigation risk suppresses the overall level of disclosure, the passage of UD laws should have a positive effect on both good news and bad news forecasts in a similar manner. However, if high litigation risk incentivizes managers to provide more bad news (Skinner [1994]), we should expect managers to opportunistically reduce bad news forecasts after the adoption of UD laws. Columns (1) and (2) of Table 6 report the corresponding results. The coefficient on $U D$ Law is significant and positive for both good news and bad news forecasts. ${ }^{20}$ Furthermore,

\footnotetext{
${ }^{20}$ In defining good and bad news, we focus on economically meaningful management earnings forecasts (Kothari et al. [2009], Das et al. [2012]). Specifically, we define a management forecast as good news (bad news) if the difference between management forecast and consensus analyst forecast scaled by the absolute value of consensus analyst forecast is greater than $10 \%$ (smaller than -10\%). We apply the same cutoff in defining optimistic or pessimistic management earnings forecasts. We drop observations if their absolute value of analyst consensus forecast (or absolute value of reported actual earnings) is no greater than 0.01. Furthermore, our results are not affected if we follow Li and Zhang [2015] and adjust forecast news using
} 
the Wald test suggests that the difference between good news and bad news forecasts is not statistically significant. These results indicate that the decrease in the derivative litigation risk does not lead managers to opportunistically disclose less bad news. In contrast, managers improve the overall level of disclosure by increasing both good news and bad news disclosures after the adoption of UD laws.

Second, we classify earnings forecasts into optimistic and pessimistic forecasts. Optimistic forecasts are those that exceed realized earnings, while pessimistic forecasts are below realized earnings. We do so because the effect of the derivative litigation risk on the biases of management forecasts could be asymmetric. Specifically, it is likely that managers are afraid of being sued for making optimistic earnings forecasts that are not realized, but it is unlikely that investors would take legal action against managers for being too pessimistic and achieving higher earnings than expected. Thus, managers would strategically shy away from optimistic earnings forecasts when facing high litigation risk. If the adoption of UD laws leads to more opportunistic disclosure behavior as opposed to an overall increase in disclosure, we should observe an increase only in optimistic forecasts, not in pessimistic forecasts. However, in columns (3) and (4) of Table 6, we find evidence that UD laws increase both optimistic and pessimistic forecasts. Furthermore, the Wald test suggests that the difference between optimistic and pessimistic forecasts is not statistically significant. Taken together, these findings further support the argument that the reduced derivative litigation risk increases the overall level of information disclosed by managers.

Finally, we examine whether low shareholder litigation risk improves the precision of management earnings forecasts. We do so because managers may have more discretion over the quality of their earnings forecasts than whether to provide the forecasts. In particular, due to managers' fiduciary duty to update and correct previous disclosures, they cannot always withhold information (Hirst et al. [2008]). Furthermore, prior studies (Baginski et al. [2002; 2007]) suggest that the usefulness of management forecasts increases with the precithe methodology proposed in Rogers and Van Buskirk [2013]. 
sion of the forecast. Column (9) Table 6 presents the corresponding results. The dependent variable in column (9) is the width of the forecast errors (WidthMF). The smaller the width, the more precise the forecast. The coefficient on UD Law is negative and statistically significant at the $1 \%$ level, suggesting that the passage of UD laws improves the precision of management earnings forecasts.

So far we have focused on firms' voluntary disclosure, in particular management earnings forecasts, to examine the impact of UD laws on corporate disclosure. However, Ball et al. [2012] argue that mandatory financial reporting and voluntary disclosure are complements, and they are two integral parts of firms' information environment. Consistent with this argument, they find that higher-quality mandatory financial reporting is associated with more frequent, specific, timely, accurate and informative management forecasts. To explore the impact of UD laws on the quality of mandatory financial reporting, we use the level of discretionary accruals based on the modified Jones model. Table 7 presents the results pertaining to the effect of UD laws on the level of discretionary accruals. In columns (1) and (2), we include only fixed effects and find that the coefficient on UD Law is negative and significant at conventional levels. We further include determinants of mandatory disclosure quality in column (3). Again, we find that the passage of UD laws leads to a decrease in the level of discretionary accruals, which indicates that UD laws also improve the quality of mandatory financial reporting.

Our analysis of discretionary accruals also serves two other purposes: First, we include all firm-year observations from 1989 to 2007 in the discretionary accruals regression, which covers the universe of U.S. states that adopted UD laws. ${ }^{21}$ We thus fully exploit the staggered adoption of UD laws and alleviate the concern that our results are driven by a few states that experience the changes in the laws. Second, the positive effect of UD laws on the quality of mandatory financial reporting also provides further evidence that high shareholder litigation

\footnotetext{
${ }^{21}$ We delete firms in the financial services (SIC 6000-6999) and utilities industries (SIC 4900-4949) in the analysis of discretionary accruals, as accounting rules are significantly different for these regulated industries. However, our results are not affected if we keep these industries in the sample.
} 
risk does not necessarily discipline managers' opportunistic behavior, and thus the reduction in shareholder litigation risk does not lead to more opportunistic reporting.

\section{Additional Analyses}

\subsection{Sensitivity Analyses}

In this sub-section, we perform several sensitivity tests to ensure the robustness of our results. We start by re-estimating our main effects by excluding various states from our sample. We report these results in Appendix Table A1. In columns (1)-(3), we exclude firms incorporated in the U.S. states that adopted UD laws before the first year of the sample period for the three voluntary disclosure measures. Specifically, we remove observations before 1998 for the management earnings forecast sample and before 1995 for the MD\&A and 8-K filings samples. This test aims at mitigating the concern that stale firm-year observations over the sample period may drive the results. Dropping these observations does not affect our findings. In particular, the coefficient on UD Law remains positive and statistically significant at conventional levels for all three voluntary disclosure measures.

Second, Houston et al. [2015] argue that the 1999 ruling of the Ninth Circuit Court of Appeals raises the hurdle of filing class action lawsuits against firms headquartered in the states of the Ninth Circuit Court. To ensure that our main result is not driven by the changes in the legal environment pertaining to class action lawsuits, we further exclude firms headquartered in states from the Ninth Circuit Court from our sample. As shown in columns (4)-(6), the effect of UD laws on the three voluntary disclosure measures remains positive and statistically significant at conventional levels.

Third, we exclude from our sample observations from firms that are incorporated in Pennsylvania. We do so because, as reported in Table 1, Pennsylvania is the treated state with the largest number of firm-year observations over our sample period. We tabulate our results in columns (7)-(9). The coefficient on UD Law remains positive and statistically significant 
at conventional levels across our three voluntary disclosure measures. This mitigates the concern that our results might be driven mostly by the largest state that adopted a UD law in the sample.

Finally, we acknowledge that about $50 \%$ of the publicly listed firms that appear in our sample are incorporated in Delaware. To ensure that the inclusion of Delaware firms in our control group does not drive our results, we re-estimate Equation (1) and drop these firms from the sample. The results in columns (10)-(12) show that our findings remain qualitatively similar if we drop firms incorporated in Delaware. Specifically, the coefficient on UD Law is positive and statistically significant at conventional levels for all three disclosure measures.

As mentioned in Section 4.2, the use of 8-K filings as a disclosure measure presents an interesting feature. It has both voluntary and mandatory components, which allows us to perform a placebo test. Specifically, if the decrease in the litigation risk mainly impacts voluntary disclosures provided by managers, we should not find any change or perhaps only an economically weak change in the frequency of mandatory 8-K filings following the implementation of UD laws. We directly test this prediction and estimate our main specification using the frequency of mandatory 8-K filings, FreqMan8k, as the dependent variable. The results are reported in Appendix Table A2, where we perform the same three specifications as in Table 3. Our difference-in-differences estimate is close to zero and not statistically significant at conventional levels. This placebo test thus provides further evidence that the adoption of UD laws primarily affects managers' voluntary disclosure decisions.

Throughout our analyses, we have defined industry-year fixed effects using the FamaFrench 30 classification. To ensure that our results are not driven by a single industry classification, we redefine our industry-year fixed effects using the Fama-French 12 and SIC two-digit industry classifications and repeat our main tests from Table 3 . We report the corresponding results in Appendix Table A3. The estimates on UD Law remain positive and statistically significant at conventional levels.

Throughout the paper, we have clustered our standard errors at the state of incorpora- 
tion level to account for potential serial correlation among groups that we use to define our treatment variable (Bertrand et al. [2004]). One concern with finite samples is that a small number of clusters may over-estimate the precision of our coefficient of interest. However, Bertrand et al. [2004] suggest that the differences-in-differences estimator performs well in finite samples when the number of clusters equals 50, while we have more than 50 clusters (52). Nevertheless, to ensure the robustness of our results, we repeat our main tests from Table 3 using alternative clustering methods. We report the corresponding results in Appendix Table A4. First, we follow Mooney and Duval [1993] and perform 50 bootstrapped replications for the main specification with the three voluntary disclosure measures. The sample drawn for each replication is a bootstrapped sample of clusters using the states of incorporation. Our results, reported in columns (1)-(3), remain statistically significant at conventional levels. Second, in columns (4)-(6), we cluster our standard errors at the firm level. This approach is not as conservative as our main approach as it does not account for serial correlation within states over time. Our difference-in-differences estimates remain statistically significant at conventional levels. Third, in columns (7)-(9), we cluster our standard errors at the state of incorporation-year level (Chaney et al. [2012]). While this approach does not account for time-series correlation, it increases the number of clusters. Our results remain unaffected. Finally, we also follow Cameron et al. [2011] and cluster our standard errors using two separate dimensions, at the state of incorporation and year levels. Our estimates are reported in columns (10)-(12). Overall, our results are not sensitive to varying the clustering dimensions.

\subsection{Adoption of UD Laws and State-level Corporate Disclosure Environment}

Appel [2016] does not find that firms endogenously choose to incorporate in U.S. states where UD laws are in place. However, one may argue that the adoption of UD laws could be affected by time-varying state-level factors. These factors can bias our estimates if they 
are also correlated with the corporate disclosure environment in a given state. To mitigate the concern that the adoption of UD laws is endogenous with respect to the state-level corporate disclosure environment, we aggregate the determinants of disclosure decisions (e.g., institutional ownership, stock return) at the state-year level and regress the passage of UD laws on these state-year level factors.

Appendix Table A5 presents the corresponding results. The dependent variable is an indicator variable that takes the value of one if a state passes a UD law in a given year. We use the treated states prior to the adoption of UD laws and conduct the analysis at the state-year level, which leads to a small number of observations. Given the small sample size, adding fixed effects in a probit model can produce inconsistent estimates (Wooldridge [2002]). To tackle this issue, we follow Wooldridge [2002] and use a Chamberlain's Random Effects (CRE) probit model. Specifically, in addition to the state-year level disclosure determinants, we include the state means of all disclosure determinants as additional control variables to account for unobservable state fixed effects. Appendix Table A5 shows that none of the coefficients on the state-year level disclosure determinants are significant, suggesting that the adoption of a UD law is not endogenous to the factors that drive corporate disclosure decisions at the state level.

\section{Conclusion}

Prior research that examines the relation between shareholder litigation risk and corporate disclosure is susceptible to measurement errors and endogenous concerns. In this paper, we take advantage of a plausibly exogenous shock to shareholder litigation risk and examine its effect on corporate disclosure. Using various disclosure measures, we find strong evidence that in response to the reduced derivative litigation risk, firms issue more earnings forecasts and voluntary 8-K filings, as well as increase the length of the MD\&A section in their 10-K filings. We thus provide evidence of a causal effect of shareholder litigation risk on corporate 
disclosure.

Furthermore, we view shareholder litigation as an integral part of corporate governance and investigate its direct and indirect effects on corporate disclosure. We find that expected costs associated with shareholder litigation are the direct channel through which shareholder litigation risk influences corporate disclosure. Furthermore, shareholder litigation also affects corporate disclosure indirectly via its role as a governance tool. In particular, the impact of shareholder litigation on corporate disclosure is more pronounced for firms for which shareholder litigation is a more important mechanism to discipline managers. 


\section{References}

Ajinkya, B.; S. Bhojraj; And P. Sengupta. "The association between outside directors, institutional investors and the properties of management earnings forecasts." Journal of Accounting Research 43 (2005): 343-376.

Ali, A.; S. Klasa; And E. Yeug. "Industry concentration and corporate disclosure policy." Journal of Accounting and Economics 58 (2004): 240-264.

Appel, I. "Governance by litigation." (2016). Working Paper.

Armstrong, C.; W. Guay; And J. Weber. "The role of information and financial reporting in corporate governance and debt contracting." Journal of Accounting and Economics 50 (2010): 179-234.

Baginski, S.; J. Hassell; And M. Kimbrough. "The effect of legal environment on voluntary disclosure: Evidence from management earnings forecasts issued in U.S. and Canadian markets." The Accounting Review 77 (2002): 25-50.

Baginski, S.; J. Hassell; And M. M. Wieland. "Does management earnings forecast form matter?" (2007). Working Paper.

Balakrishnan, K.; M. Billings; B. Kelly; And A. Luungqvist. "Shaping liquidity: On the causal effects of voluntary disclosure." Journal of Finance 69 (2014a): 2237-2278.

Balakrishnan, K.; J. Core; And R. Verdi. "The relation between reporting quality and financing and investment: Evidence from shocks to financing capacity." Journal of Accounting Research 52 (2014b): 1-39.

Ball, R.; S. Jayaraman; And L. Shivakumar. "Audited financial reporting and voluntary disclosure as complements: A test of the confirmation hypothesis." Journal of Accounting and Economics 53 (2012): 136-166.

Bertrand, M.; E. Duflo; And S. Mullainathan. "How much should we trust differences-in-differences estimates?" Quarterly Journal of Economics 119 (2004): 249275.

Bertrand, M. And S. Mullainathan. "Enjoying the quiet life? Corporate governance and managerial preferences." Journal of Political Economy 111 (2003): 1043-1075. 
Beyer, A.; D. Cohen; T. Lys; And B. Walther. "The financial reporting environment: Review of the recent literature." Journal of Accounting and Economics 50 (2010): 296343.

Billings, M. B. And M. Cedergren. "Strategic silence, insider selling and litigation risk." Journal of Accounting and Economics 59 (2015): 119-142.

Bloomfield, R. "Discussion of "Annual report readability, current earnings, and earnings persistence'." Journal of Accounting and Economics 45 (2008): 248-252.

Boone, A. And J. White. "The effect of institutional ownership on firm transparency and information production." Journal of Financial Economics 117 (2015): 508-533.

Brochet, F. and S. SRinivasan. "Accountability of independent directors: Evidence from firms subject to securities litigation." Journal of Financial Economics 111 (2014): $430-449$.

Brown, L.; A. Call; M. Clement; and N. Sharp. "Inside the 'black box' of sell-side financial analysts." Journal of Accounting Research 53 (2015): 1-47.

Brown, S. AND J. TuCKER. "Large-sample evidence on firms' year-over-year MD\&A modifications." Journal of Accounting Research 49 (2011): 309-346.

Cameron, A.; J. Gelbach; And D. Miller. "Robust inference with multi-way clustering." Journal of Business and Economic Statistics 29 (2011): 1-28.

Carter, M. E. And B. Soo. "The relevance of Form 8-K reports." Journal of Accounting Research 37 (1999): 119-132.

Chaney, T.; D. Sraer; And D. Thesmar. "The collateral channel: How real estate shocks affect corporate investment." American Economic Review 102 (2012): 2381-2409.

Chen, S.; D. Matsumoto; And S. Rajgopal. "Is silence golden? An empirical analysis of firms that stop giving quarterly earnings guidance." Journal of Accounting and Economics 51 (2011): 134-150.

Cheng, A.; H. Huang; Y. Li; And G. Lobo. "Institutional monitoring through shareholder litigation." Journal of Financial Economics 95 (2010): 356-383.

Cheng, Q. And K. Lo. "Insider trading and voluntary disclosures." Journal of Financial Economics 44 (2006): 815-848. 
Chu, Y. AND Y. Zhao. "The dark side of shareholder litigation: Evidence from corporate takeovers." (2015). Working Paper.

Chuk, E.; D. Matsumoto; And G. Miller. "Assessing methods of identifying management forecasts: CIG vs. researcher collected." Journal of Accounting and Economics 55 (2013): 23-42.

Cooper, M.; J. He; And M. PlumleE. "Measuring disclosure using 8-K filings." (2016). Working Paper.

CotTer, J.; I. TunA; And P. Wysocki. "Expectations management and beatable targets: How do analysts react to explicit earnings guidance?" Contemporary Accounting Research 23 (2006): 593-624.

Cox, J. D. "The social meaning of shareholder suits." Brooklyn Law Review 65 (1999): $3-45$.

Crane, A. And A. Koch. "Shareholder litigation and ownership structure: Evidence from a natural experiment." Management Science (2017). Forthcoming.

DAS, S.; K. Kim; AND S. PATRO. "On the anomalous stock response to management earnings forecasts." Journal of Business Finance and Accounting 39 (2012): 905-935.

ERICKSON, J. "Corporate governance in the courtroom: An empirical analysis." William and Mary Law Review 51 (2010): 1749-1831.

Feldman, R.; S. Govindaraj; J. Livnat; And B. Segal. "Management's tone change, post earnings announcement drift and accruals." Review of Accounting Studies 15 (2010): $915-953$.

Ferreira, M. And P. A. Laux. "Corporate governance, idiosyncratic risk, and information flow." Journal of Finance LXII (2007): 951-989.

FERRIS, S.; T. JANDIK; AND R. LAWLESS. "Derivative lawsuits as corporate governance mechanism: Empirical evidence on board changes surrounding filings." Journal of Financial and Quantitative Analysis 42 (2007): 143-165.

Field, L.; M. LOWRY; AND S. SHu. "Does disclosure deter or trigger litigation?" Journal of Financial and Quantitative Analysis 39 (2005): 487-507.

Francis, J.; D. Philbrick; And K. Schipper. "Shareholder litigation and corporate disclosure." Journal of Accounting Research 32 (1994): 137-164. 
Frankel, R.; M. MCNichols; and G. Wilson. "Discretionary disclosure and external financing." The Accounting Review 70 (1995): 135-150.

FROST, C. "Disclosure policy choices of UK firms receiving modified audit reports." Journal of Accounting and Economics 23 (1997): 163-187.

FU, H. AND M. LiU. "Anti-takeover provisions and corporate disclosure." (2007). Working Paper.

Gormley, T. And D. MAtsa. "Growing out of trouble? Corporate responses to liability risk." Review of Financial Studies 24 (2011): 2781-2821.

Gormley, T. And D. Matsa. "Common errors: How to (and not to) control for unobserved heterogeneity." Review of Financial Studies 27 (2014): 617-661.

Gow, I.; D. LARCKER; AND P. ReISS. "Causal inference in accounting research." Journal of Accounting Research 54 (2016): 477-523.

Graham, J.; C. Harvey; And S. Rajgopal. "The economic implications of corporate financial reporting." Journal of Accounting and Economics 40 (2005): 3-73.

Hirst, D.; L. Koonce; And S. Venkataraman. "Management earnings forecasts: A review and framework." Accounting Horizons 22 (2008): 315-338.

Houston, J.; C. Lin; S. LiU; And L. WEI. "Shareholder litigation and management earnings forecasts." (2015). Working Paper.

Hutton, A. "Determinants of managerial earnings guidance prior to Regulation Fair Disclosure and bias in analysts' earnings forecasts." Contemporary Accounting Research 22 (2005): 867-914.

Imbens, G. And D. Rubin. Causal inference for statistics, social, and biomedical sciences - An introduction. Cambridge University Press (2015).

JEnsen, M. "The modern industrial revolution, exit, and the failure of internal control systems." Journal of Finance 48 (1993): 831-880.

JIA, Y.; L. VAN LENT; AND Y. ZENG. "Masculinity, testosterone, and financial misreporting." Journal of Accounting Research 52 (2014): 1195-1246.

JIN, L. AND S. MyeRs. "R-squared around the world: New theory and new tests." Journal of Financial Economics 25 (2006): 605-648. 
Johnson, M.; R. Kasznik; And K. Nelson. "The impact of securities litigation reform on the disclosure of forward-looking information by high technology firms." Journal of Accounting Research 3 (2001): 297-327.

Karamanou, I. And N. Vafeas. "The association between corporate boards, audit committees, and management earnings forecasts: An empirical analysis." Journal of Accounting Research 43 (2005): 453-486.

KASzNiK, R. AND B. LEV. "To warn or not to warn: Management disclosures in the face of an earnings surprise." The Accounting Review 70 (1995): 113-134.

Kim, I. AND D. Skinner. "Measuring securities litigation risk." Journal of Accounting and Economics 53 (2012): 290-310.

Kothari, S.; S. Shu; AND D. Wysocki. "Do managers withhold bad news?" Journal of Accounting Research 47 (2009): 241-276.

LANG, M. AND R. Lundholm. "Cross-sectional determinants of analyst ratings of corporate disclosure." Journal of Accounting Research 31 (1993): 246-271.

Lennox, C. And C. PARK. "The informativeness of earnings and management's issuance of earnings forecasts." Journal of Accounting and Economics 42 (2006): 439-458.

Lerman, A. And J. Livnat. "The new Form 8-K disclosures." Review of Accounting Studies 15 (2010): 752-778.

Leuz, C. And C. Schrand. "Disclosure and the cost of capital: Evidence from firms' responses to the Enron shock." (2009). Working Paper.

LI, F. "Annual report readability, current earnings, and earnings persistence." Journal of Accounting and Economics 45 (2008): 221-247.

LI, F. "The information content of forward-looking statements in corporate filings - A naive Bayesian machine learning algorithm approach." Journal of Accounting Research 48 (2010): 1049-1102.

Li, Y. AND L. Zhang. "Short selling pressure, stock price, behavior, and management forecast precision: Evidence from a natural experiment." Journal of Accounting Research 53 (2015): 79-117. 
Lo, A. "Do declines in bank health affect borrowers' voluntary disclosures? Evidence from international propagation of banking shocks." Journal of Accounting Research 52 (2014): $541-581$.

Loughran, T. and B. McDonald. "Measuring readability in financial disclosures." Journal of Finance 69 (2014): 1643-1671.

Matsumoto, D. "Management's incentives to avoid negative earnings surprises." The Accounting Review 77 (2002): 483-514.

MilleR, G. "Earnings performance and discretionary disclosure." Journal of Accounting Research 40 (2002): 173-204.

Mooney, C. And R. Duval. Bootstrapping: A nonparametric approach to statistical inference. Sage, Newbury Park, California (1993).

Newman, P. And R. Sansing. "Disclosure policies with multiple users." Journal of Accounting Research 31 (1993): 92-112.

Rogers, J. And P. Stocken. "Credibility of management forecasts." The Accounting Review 80 (2005): 1233-1260.

Rogers, J. AND A. VAn Buskirk. "Shareholder litigation and changes in disclosure behavior." Journal of Accounting and Economics 47 (2009): 136-156.

Rogers, J. AND A. VAN Buskirk. "Bundled forecasts in empirical accounting research." Journal of Accounting and Economics 55 (2013): 43-65.

Schoenfeld, J. "The effect of voluntary disclosure on stock liquidity: New evidence from index funds." Journal of Accounting and Economics 63 (2017): 51-74.

Schrand, C. and S. Zechman. "Executive overconfidence and the slippery slope to financial misreporting." Journal of Accounting and Economics 53 (2012): 311-329.

SEo, H. "Peer effects in corporate disclosure decisions." (2016). Working Paper.

Shleifer, A. And R. Vishny. "A survey of corporate governance." Journal of Finance 52 (1997): 737-783.

Shroff, N.; A. Sun; H. White; And W. Zhang. "Voluntary disclosure and information asymmetry: Evidence from the 2005 securities offering reform." Journal of Accounting Research 51 (2013): 1299-1345. 
SkinneR, D. "Why firms voluntarily disclose bad news." Journal of Accounting Research 32 (1994): 38-60.

Skinner, D. "Earnings disclosures and stockholder lawsuits." Journal of Accounting and Economics 23 (1997): 249-282.

SRINIVASAN, S. "Consequences of financial reporting failure for outside directors: Evidence from accounting restatements and audit committee members." Journal of Accounting Research 43 (2005): 291-334.

Strahan, P. E. "Securities class actions, corporate governance and managerial agency problems." (1998). Working Paper.

SwAnson, C. "Juggling shareholder rights and strike suits in derivative litigation: The ALI drops the ball." Minnesota Law Review 77 (1993): 1339-1392.

Thompson, R. "Preemption and federalism in corporate governance: Protecting shareholder rights to vote, sell, and sue." Law and Contemporary Problems 62 (1999): 215-242.

WAYMiRe, G. "Earnings volatility and voluntary management forecast disclosure." Journal of Accounting Research 23 (1985): 268-295.

Wooldridge, J. Econometric analysis of cross section and panel data. The MIT Press (2002). 
Table 1: Observations per Treated States

\begin{tabular}{lccc}
\hline & $(1)$ & $(2)$ & $(3)$ \\
\hline States & MF Sample & MDA Sample & 8K Sample \\
\hline North Carolina & 360 & 184 & 448 \\
Arizona & 116 & 71 & 140 \\
Nebraska & 34 & 14 & 46 \\
Connecticut & 154 & 95 & 228 \\
Maine & 43 & 25 & 69 \\
Pennsylvania & 981 & 529 & 1,193 \\
Texas & 743 & 527 & 972 \\
Wyoming & 15 & 4 & 20 \\
Idaho & 30 & 16 & 28 \\
Hawaii & 38 & 17 & 47 \\
Iowa & 102 & 52 & 130 \\
Massachusetts & 671 & 409 & 919 \\
Rhode Island & 64 & 43 & 87 \\
South Dakota & 29 & 7 & 35 \\
\hline Total & 3,380 & 1,993 & 4,362 \\
\hline
\end{tabular}

This table lists the number of observations per state that adopted universal demand (UD) laws over our sample period of 1995-2007, except for management forecasts, which we start in 1998 following Chuk et al. [2013]. In columns (1), (2), and (3), we report the number of observations per treated state for our samples of management forecasts, MD\&A, and 8-K filings, respectively. 
Table 2 - Descriptive Statistics

Panel A: Summary Statistics

\begin{tabular}{lcccccc}
\hline Variables & $\mathrm{N}$ & Mean & Std. Dev. & P25 & Median & P75 \\
\hline FreqMF & 30,873 & 0.5997 & 0.8451 & 0.0000 & 0.0000 & 1.0986 \\
LengthMDA & 19,413 & 8.5767 & 0.6824 & 8.1056 & 8.6268 & 9.0828 \\
FreqVol8k & 39,055 & 1.1018 & 0.9325 & 0.0000 & 1.0986 & 1.9459 \\
UD Law & 39,055 & 0.1688 & 0.3745 & 0.0000 & 0.0000 & 0.0000 \\
Institutional ownership & 39,055 & 0.3972 & 0.2865 & 0.1328 & 0.3774 & 0.6357 \\
Firm size & 39,055 & 5.6746 & 2.1009 & 4.1170 & 5.6267 & 7.1208 \\
Book-to-market & 39,055 & 0.6288 & 0.4817 & 0.3110 & 0.5140 & 0.7906 \\
ROA & 39,055 & 0.0149 & 0.1631 & 0.0042 & 0.0345 & 0.0823 \\
Stock return & 39,055 & 0.0399 & 0.5982 & -0.3020 & -0.0458 & 0.2352 \\
Earnings volatility & 39,055 & 0.1232 & 0.2440 & 0.0219 & 0.0499 & 0.1169 \\
Loss & 39,055 & 0.2301 & 0.4209 & 0.0000 & 0.0000 & 0.0000 \\
Class action litigation risk & 39,055 & 0.1254 & 0.1368 & 0.0068 & 0.0615 & 0.2342 \\
\hline
\end{tabular}

Panel B: Ex Ante Characteristics

\begin{tabular}{lccc}
\hline Variables & Eventually Treated & Never Treated & Difference \\
\hline FreqMF & 0.3776 & 0.4162 & -0.0386 \\
LengthMDA & 7.9722 & 8.4443 & $-0.4721^{* * *}$ \\
FreqVol8k & 0.3570 & 0.6739 & $-0.3168^{* * *}$ \\
Institutional ownership & 0.3157 & 0.3477 & -0.0320 \\
Firm size & 4.9961 & 5.4522 & $-0.4562^{* *}$ \\
Book-to-market & 0.5654 & 0.5810 & -0.0156 \\
ROA & 0.0359 & -0.0052 & $0.0412^{* *}$ \\
Stock return & 0.0519 & 0.0535 & -0.0016 \\
Earnings volatility & 0.0981 & 0.1781 & $-0.0799^{* * *}$ \\
Loss & 0.2149 & 0.2782 & -0.0633 \\
Class action litigation risk & 0.1175 & 0.1302 & -0.0126 \\
\hline
\end{tabular}

Panel A of Table 2 presents the summary statistics for the dependent and independent variables used in our empirical analyses. Our sample period covers the years 1995-2007 except for FreqMF, for which we start in 1998 following Chuk et al. [2013]. Detailed variable definitions are in Appendix C. Panel B of Table 2 presents the univariate comparisons between the pre-treatment values for firms incorporated in UD states ("eventually treated") and those incorporated elsewhere ("never treated") during the sample period of 1998-2007. We exclude observations that were already treated at the beginning of our sample period and compare firm-year observations that will eventually receive the treatment to those that will never receive it during the sample period. Detailed variable definitions are in Appendix C. *, ${ }^{* *}$, and $* * *$ represent significance at the $10 \%, 5 \%$, and $1 \%$ level, respectively. 


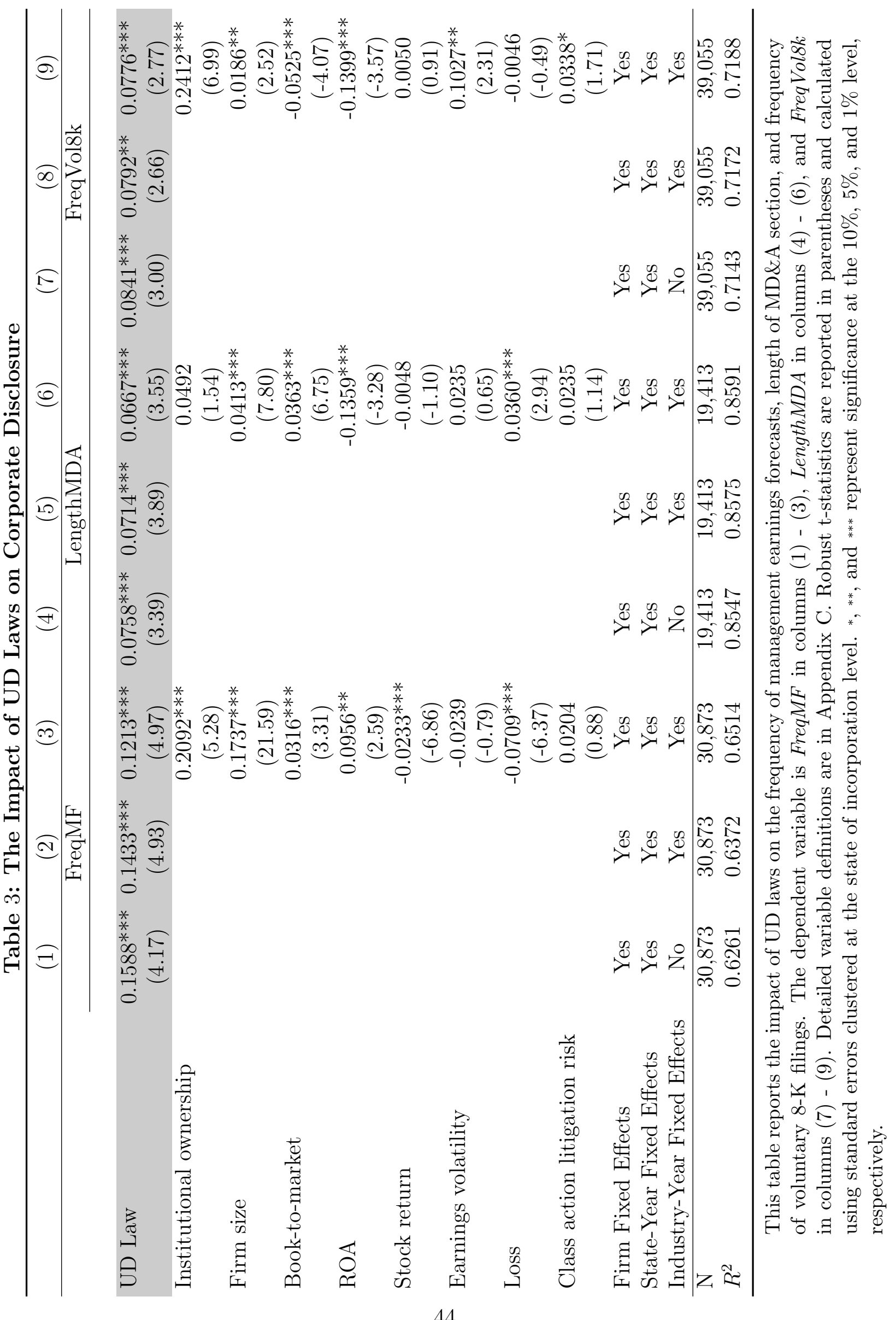


Table 4: Trend Tests of UD Laws on Corporate Disclosure

\begin{tabular}{|c|c|c|c|}
\hline & $(1)$ & $(2)$ & $(3)$ \\
\hline & FreqMF & LengthMDA & FreqVol8k \\
\hline $\mathrm{UD} \operatorname{Law}(=-1)$ & $\begin{array}{c}0.0172 \\
(0.73)\end{array}$ & $\begin{array}{l}0.0373 \\
(1.21)\end{array}$ & $\begin{array}{c}0.0023 \\
(0.14)\end{array}$ \\
\hline UD Law $(=0)$ & $\begin{array}{c}0.0810^{* * *} \\
(3.88)\end{array}$ & $\begin{array}{c}0.0914^{* *} \\
(2.46)\end{array}$ & $\begin{array}{c}0.0660^{*} \\
(1.71)\end{array}$ \\
\hline UD Law $(=+1)$ & $\begin{array}{c}0.1433^{* * * *} \\
(4.58)\end{array}$ & $\begin{array}{c}0.0858^{* * *} \\
(2.94)\end{array}$ & $\begin{array}{c}0.1019^{* * *} \\
(2.77)\end{array}$ \\
\hline UD Law $(>=+2)$ & $\begin{array}{c}0.1456^{* * * *} \\
(4.52)\end{array}$ & $\begin{array}{c}0.0791^{* * *} \\
(3.35)\end{array}$ & $\begin{array}{c}0.0762^{* *} \\
(2.29)\end{array}$ \\
\hline Institutional ownership & $\begin{array}{c}0.2091^{* * *} \\
(5.29)\end{array}$ & $\begin{array}{c}0.0492 \\
(1.53)\end{array}$ & $\begin{array}{c}0.2411^{* * *} \\
(6.98)\end{array}$ \\
\hline Firm size & $\begin{array}{c}0.1736^{* * *} \\
(21.55)\end{array}$ & $\begin{array}{c}0.0412^{* * * *} \\
(7.65)\end{array}$ & $\begin{array}{c}0.0185^{* *} \\
(2.53)\end{array}$ \\
\hline Book-to-market & $\begin{array}{c}0.0316^{* * *} \\
(3.31)\end{array}$ & $\begin{array}{c}0.0364^{* * * *} \\
(6.70)\end{array}$ & $\begin{array}{c}-0.0526^{* * *} \\
(-4.08)\end{array}$ \\
\hline $\mathrm{ROA}$ & $\begin{array}{c}0.0960^{* *} \\
(2.61)\end{array}$ & $\begin{array}{c}-0.1360 * * * \\
(-3.27)\end{array}$ & $\begin{array}{c}-0.1398^{* * *} \\
(-3.58)\end{array}$ \\
\hline Stock return & $\begin{array}{c}-0.0233^{* * *} \\
(-6.85)\end{array}$ & $\begin{array}{r}-0.0047 \\
(-1.07)\end{array}$ & $\begin{array}{c}0.0050 \\
(0.91)\end{array}$ \\
\hline Earnings volatility & $\begin{array}{c}-0.0239 \\
(-0.79)\end{array}$ & $\begin{array}{c}0.0240 \\
(0.66)\end{array}$ & $\begin{array}{c}0.1029^{* *} \\
(2.30)\end{array}$ \\
\hline Loss & $\begin{array}{c}-0.0709 * * * \\
(-6.37)\end{array}$ & $\begin{array}{c}0.0360^{* * * *} \\
(2.91)\end{array}$ & $\begin{array}{c}-0.0045 \\
(-0.49)\end{array}$ \\
\hline Class action litigation risk & $\begin{array}{l}0.0207 \\
(0.89)\end{array}$ & $\begin{array}{c}0.0233 \\
(1.14)\end{array}$ & $\begin{array}{c}0.0339^{*} \\
(1.71)\end{array}$ \\
\hline Firm Fixed Effects & Yes & Yes & Yes \\
\hline State-Year Fixed Effects & Yes & Yes & Yes \\
\hline Industry-Year Fixed Effects & Yes & Yes & Yes \\
\hline $\mathrm{N}$ & 30,873 & 19,413 & 39,055 \\
\hline$R^{2}$ & 0.6514 & 0.8591 & 0.7187 \\
\hline
\end{tabular}

This table reports the trend tests pertaining to the impact of UD laws on the frequency of management earnings forecasts, length of MD\&A section, and frequency of voluntary 8-K filings. The dependent variable is FreqMF in column (1), LengthMDA in column (2), and FreqVolsk in column (3). Detailed variable definitions are in Appendix C. Robust t-statistics are reported in parentheses and calculated using standard errors clustered at the state of incorporation level. ${ }^{*}, * *$, and $* * *$ represent significance at the $10 \%, 5 \%$, and $1 \%$ level, respectively. 


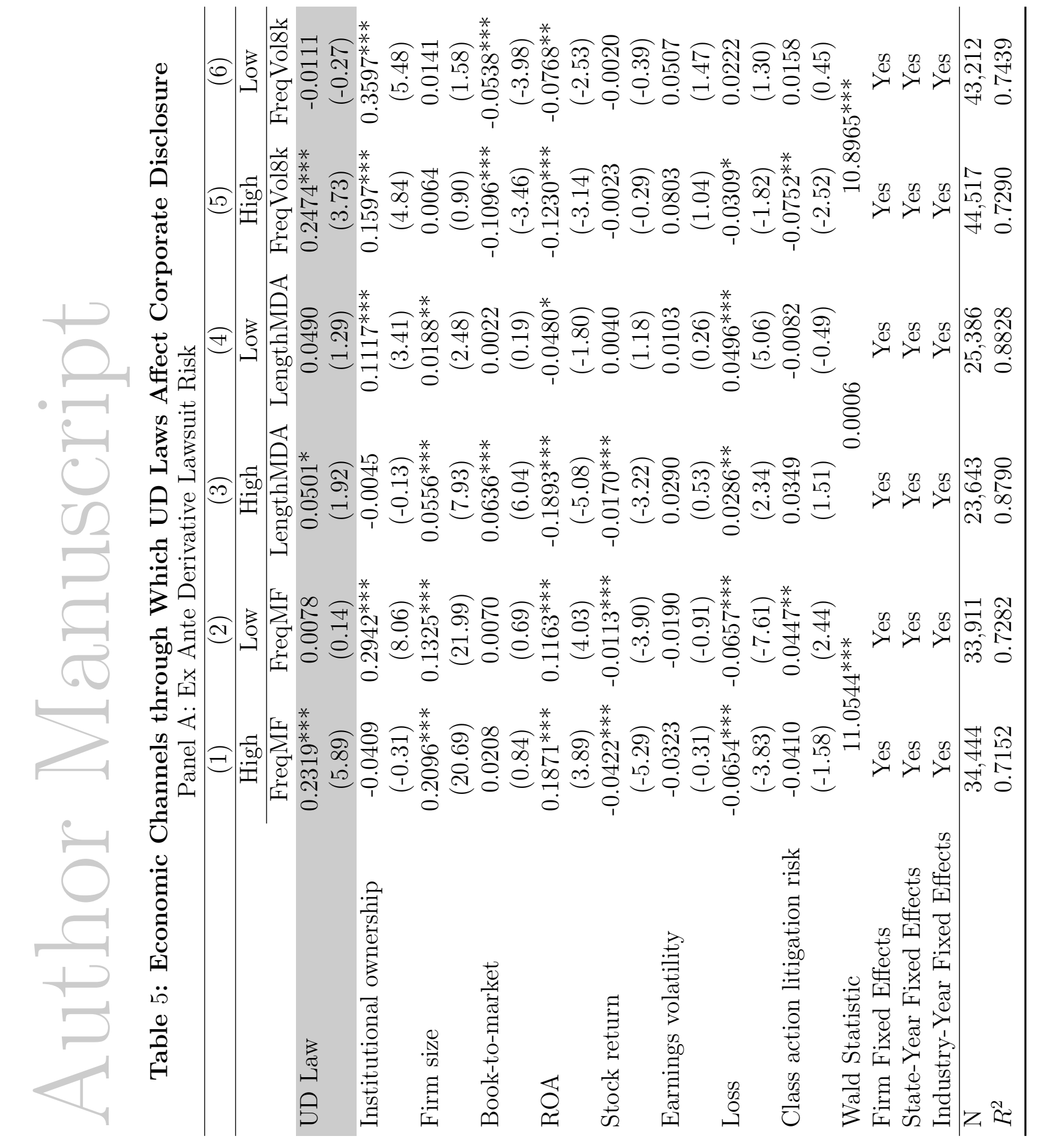

匀.

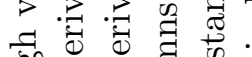
- 0 व $\exists \approx \pi \approx 0$

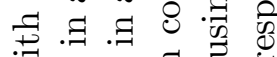

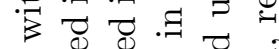
प $\therefore 00000$

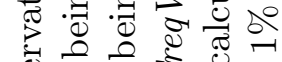

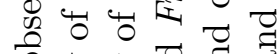

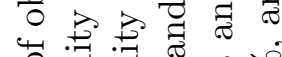
o - o d

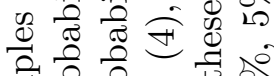
范 की क 至 ర્ન

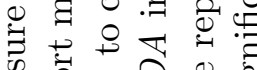
के 券 0 只 空

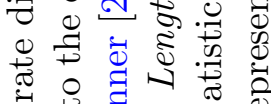

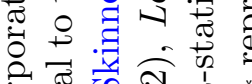

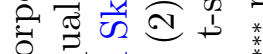

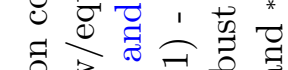

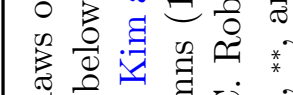

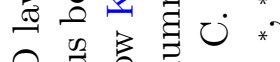

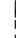
૫

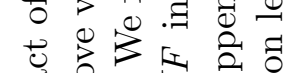

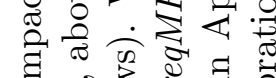
.

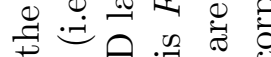

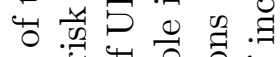

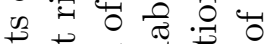
表: 表

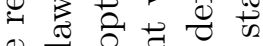
†

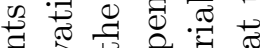
प. పี 눙

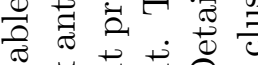

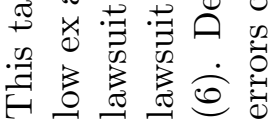




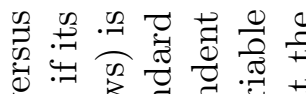

0 政

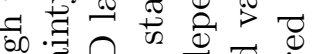

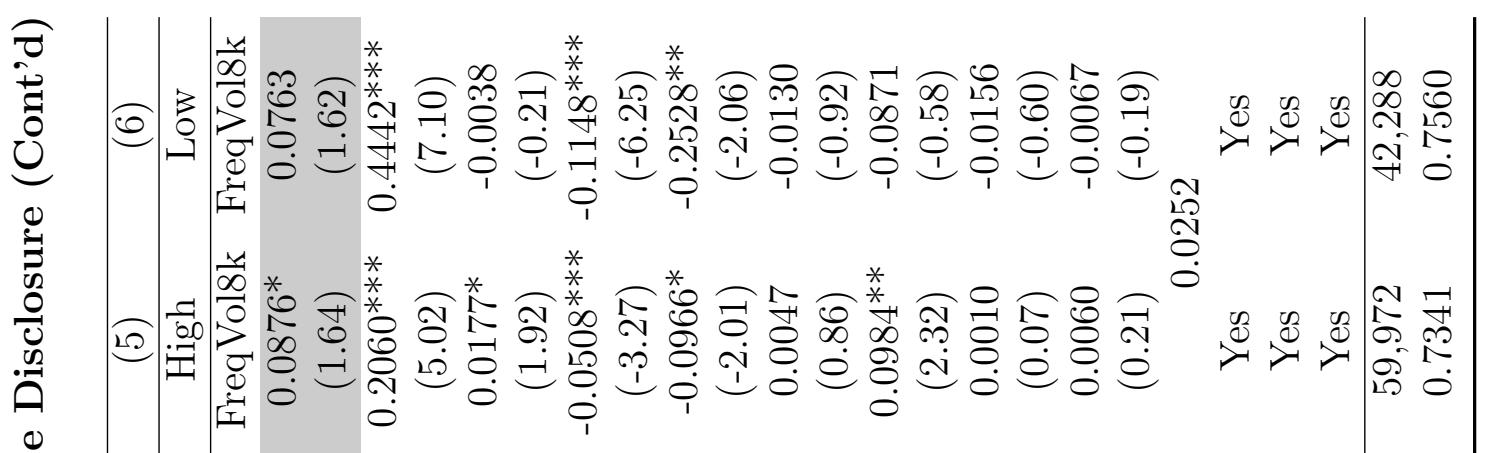
可 0

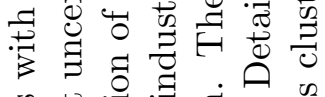

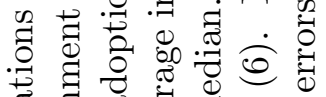
:

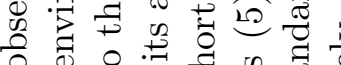
山ै

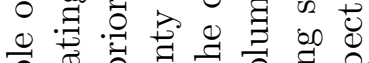

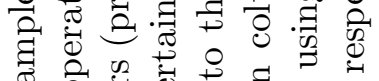

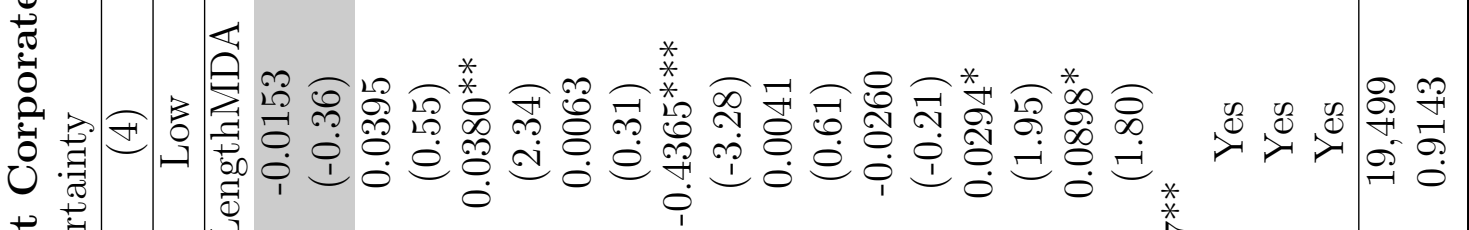

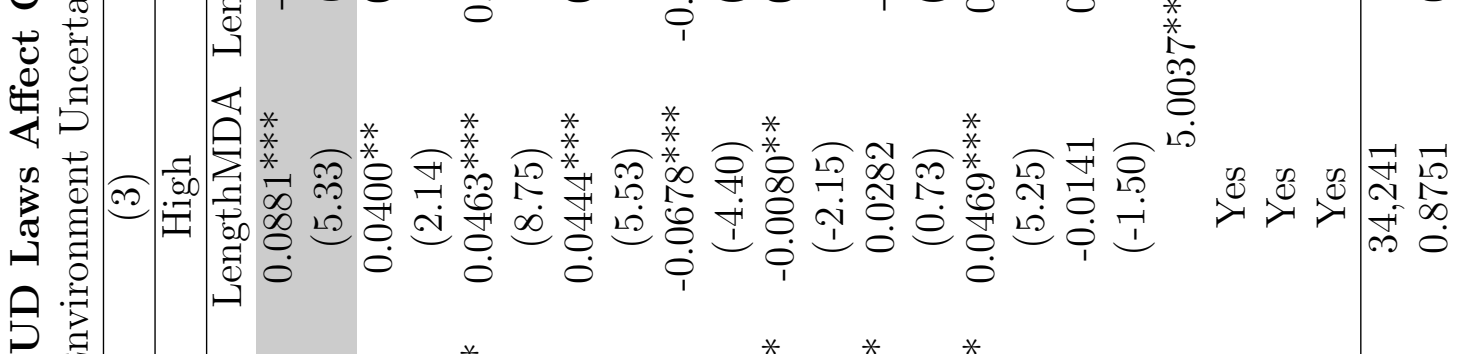
舀

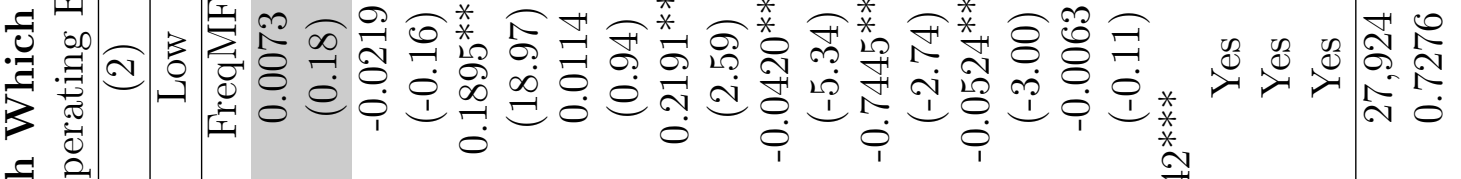

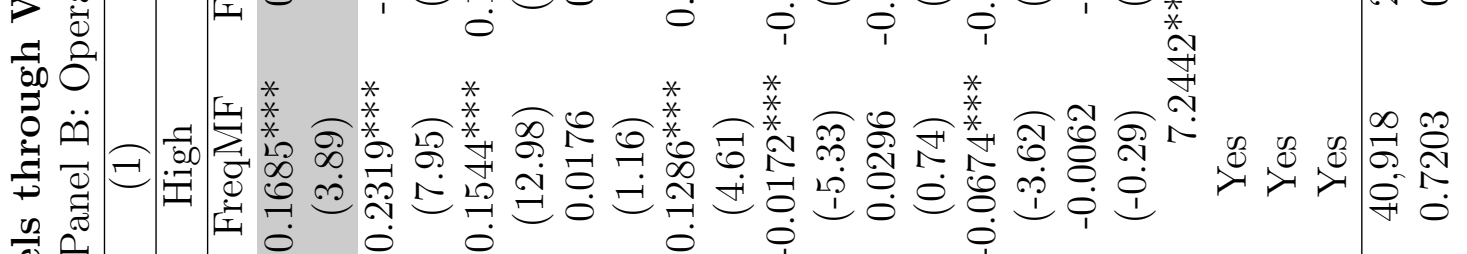

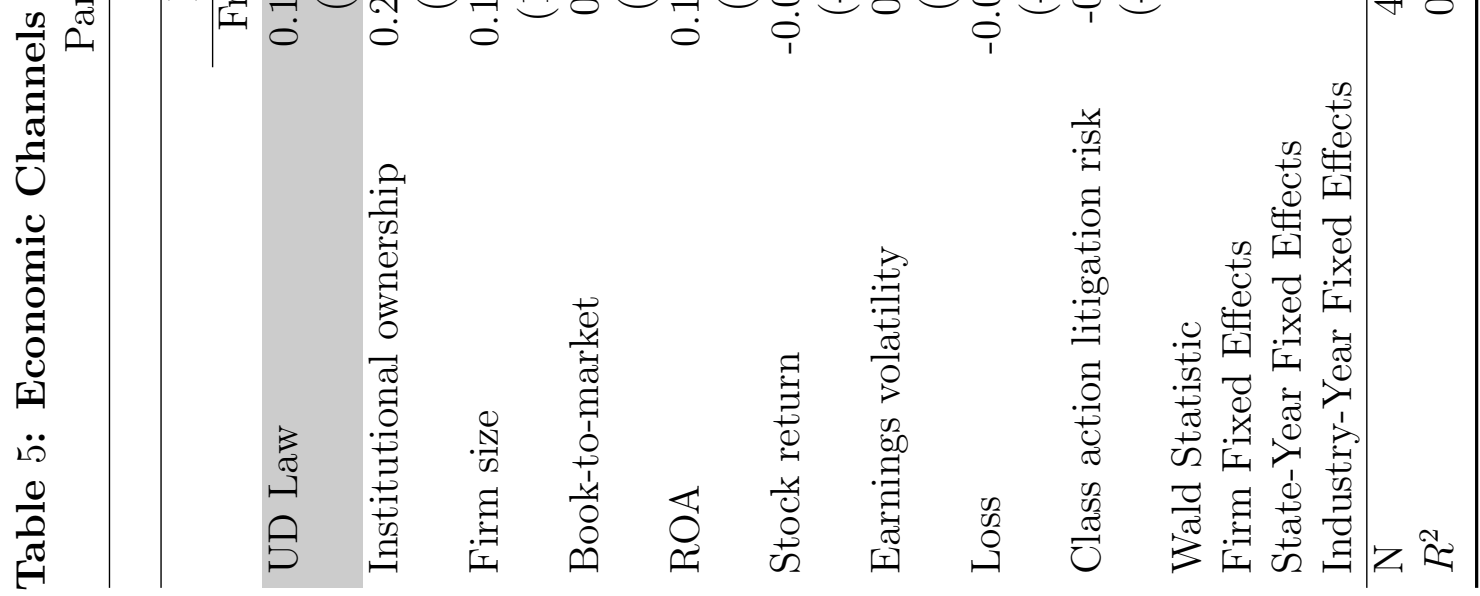
है

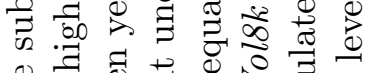
击

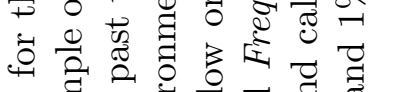
ปี

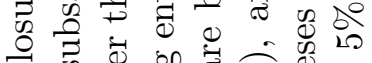
总

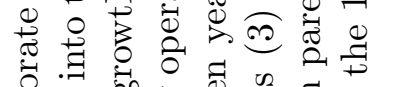

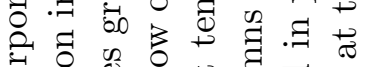

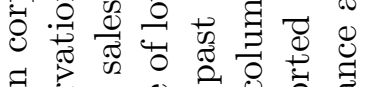

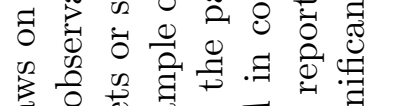

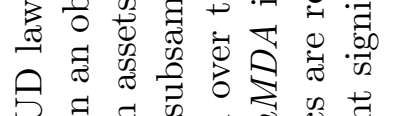

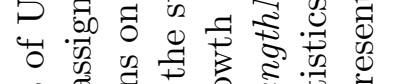

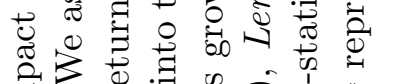

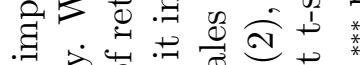

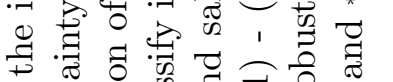

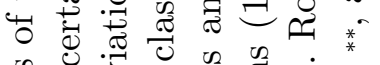

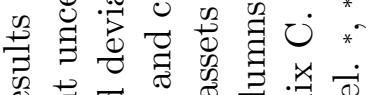

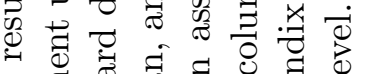

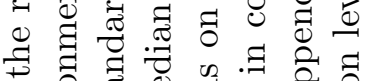

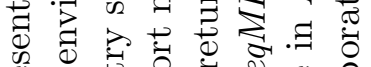

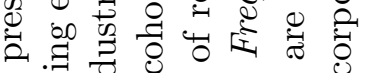

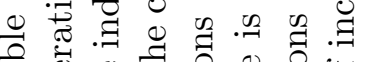
蛋

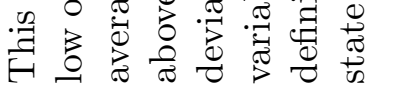




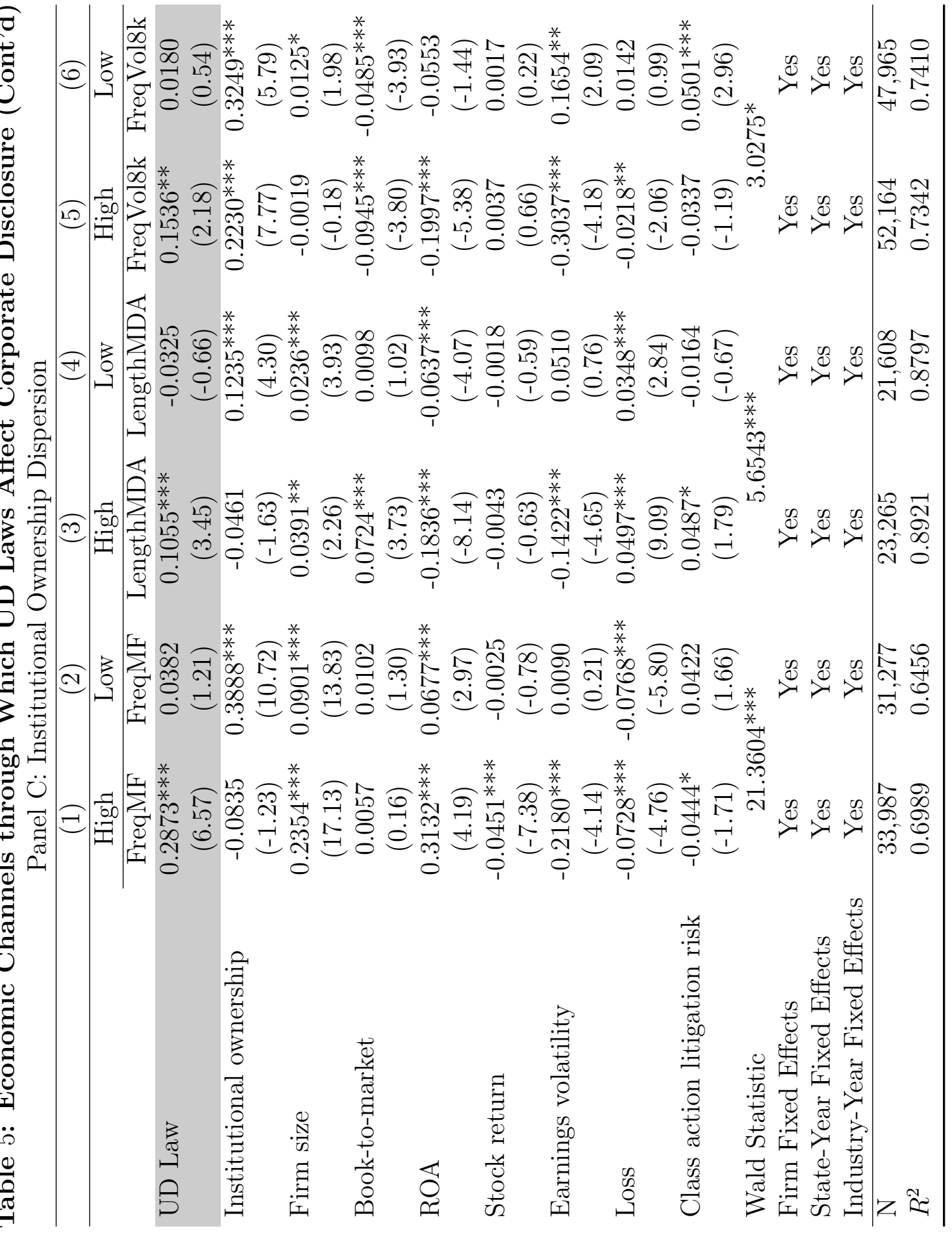

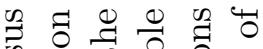

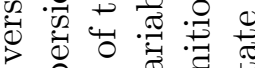

- की क्ष

然艺

을 하웡

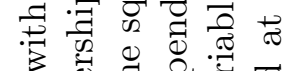

o

음

羟

o.

○ $¥$

o. 氙

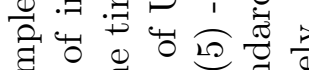

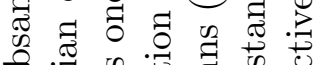

के تٓ

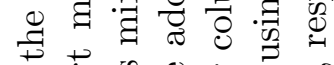

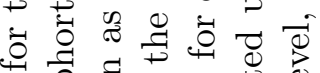

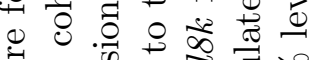

के

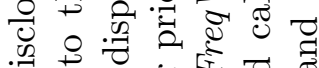

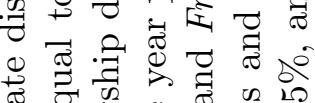

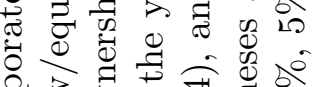

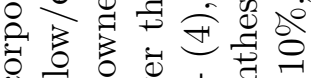

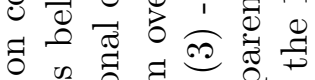

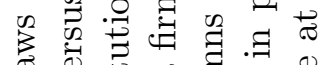

\%

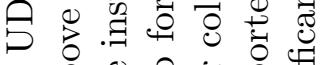

पै ते

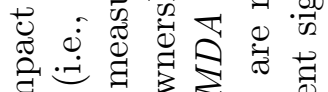

青

ॠ

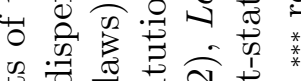

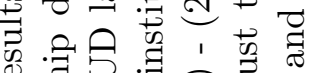

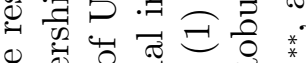

\%

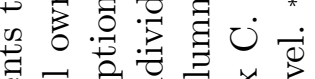

司 元

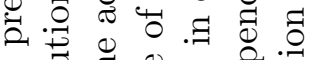

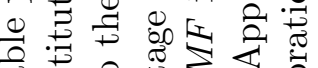

『̛.

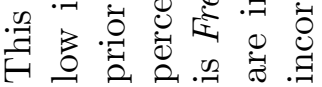




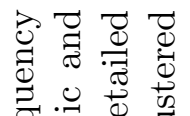

总. 聪

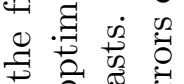

झ :

पै 00

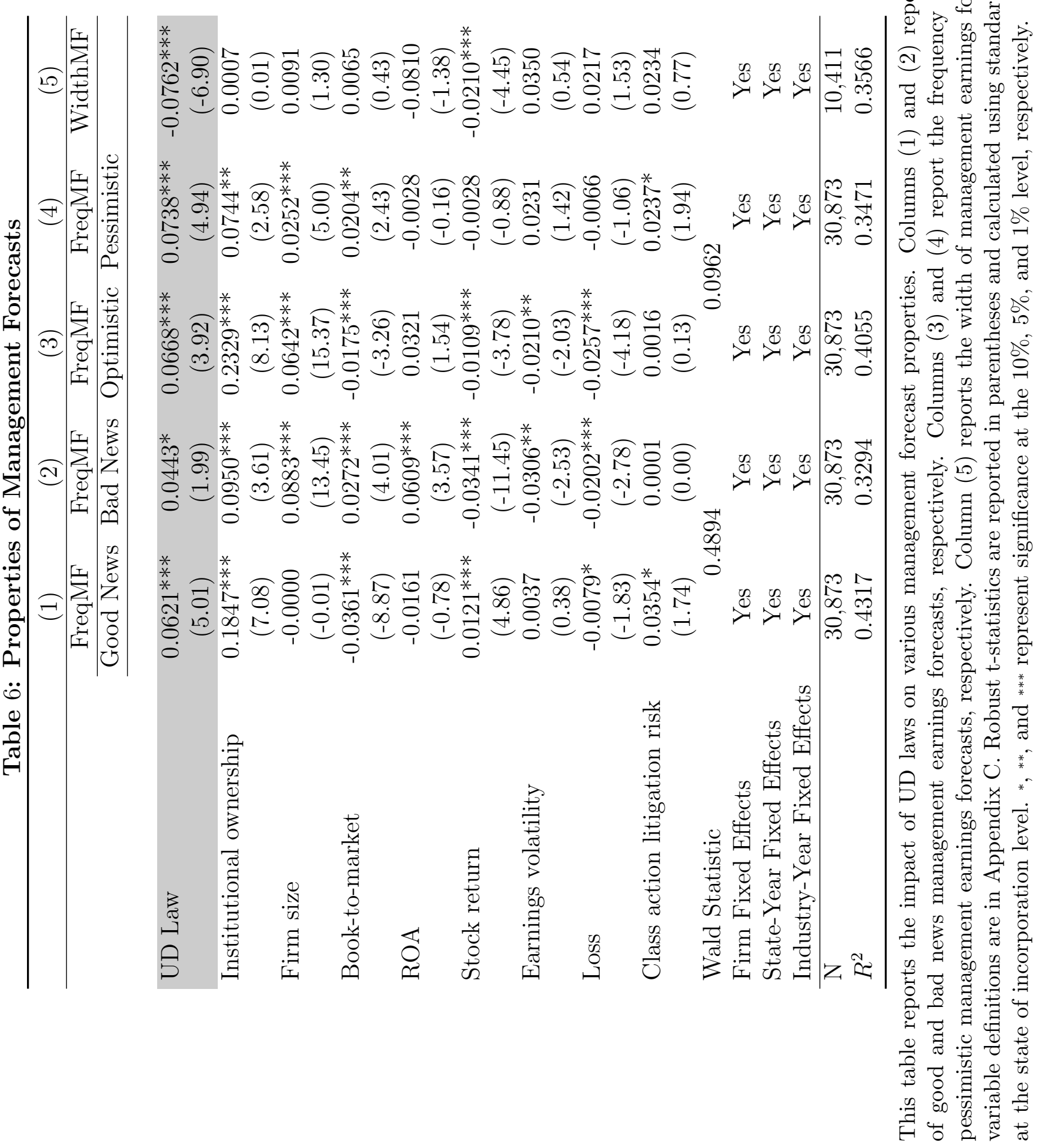


Table 7: The Impact of UD Laws on the Quality of Mandatory Disclosure

\begin{tabular}{lccc}
\hline & $(1)$ & $(2)$ & $(3)$ \\
\hline & DisAcc & DisAcc & DisAcc \\
\cline { 2 - 4 } UD Law & & & \\
& $-0.0099^{* *}$ & $-0.0085^{*}$ & $-0.0079^{*}$ \\
Institutional ownership & $(-2.34)$ & $(-1.89)$ & $(-1.76)$ \\
Firm size & & & $-0.0432^{* * *}$ \\
& & & $(-6.39)$ \\
Book-to-market & & & $-0.0058^{* * *}$ \\
& & & $(-3.95)$ \\
ROA & & & $-0.0343^{* * *}$ \\
& & & $(-16.87)$ \\
Stock return & & & $0.0516^{* * *}$ \\
& & & $(5.00)$ \\
Earnings volatility & & & $0.0068^{* * *}$ \\
& & & $(4.76)$ \\
Loss & & & $0.0294^{* * *}$ \\
& & & $(3.55)$ \\
Class action litigation risk & & & $-0.0051^{*}$ \\
& & & $(-1.84)$ \\
Firm Fixed Effects & & & 0.0068 \\
State-Year Fixed Effects & Yes & Yes & $(1.57)$ \\
Industry-Year Fixed Effects & No & Yes & Yes \\
N $R^{2}$ & 42,565 & 42,565 & 42,565 \\
\hline & 0.1917 & 0.2155 & 0.2284 \\
\hline
\end{tabular}

This table reports the impact of UD laws on the level of discretionary accruals. We calculate the level of discretionary accruals based on the modified Jones model. Detailed variable definitions are in Appendix C. Robust t-statistics are reported in parentheses and calculated using standard errors clustered at the state of incorporation level. *, ${ }^{* *}$, and ${ }^{* * *}$ represent significance at the $10 \%, 5 \%$, and $1 \%$ level, respectively. 


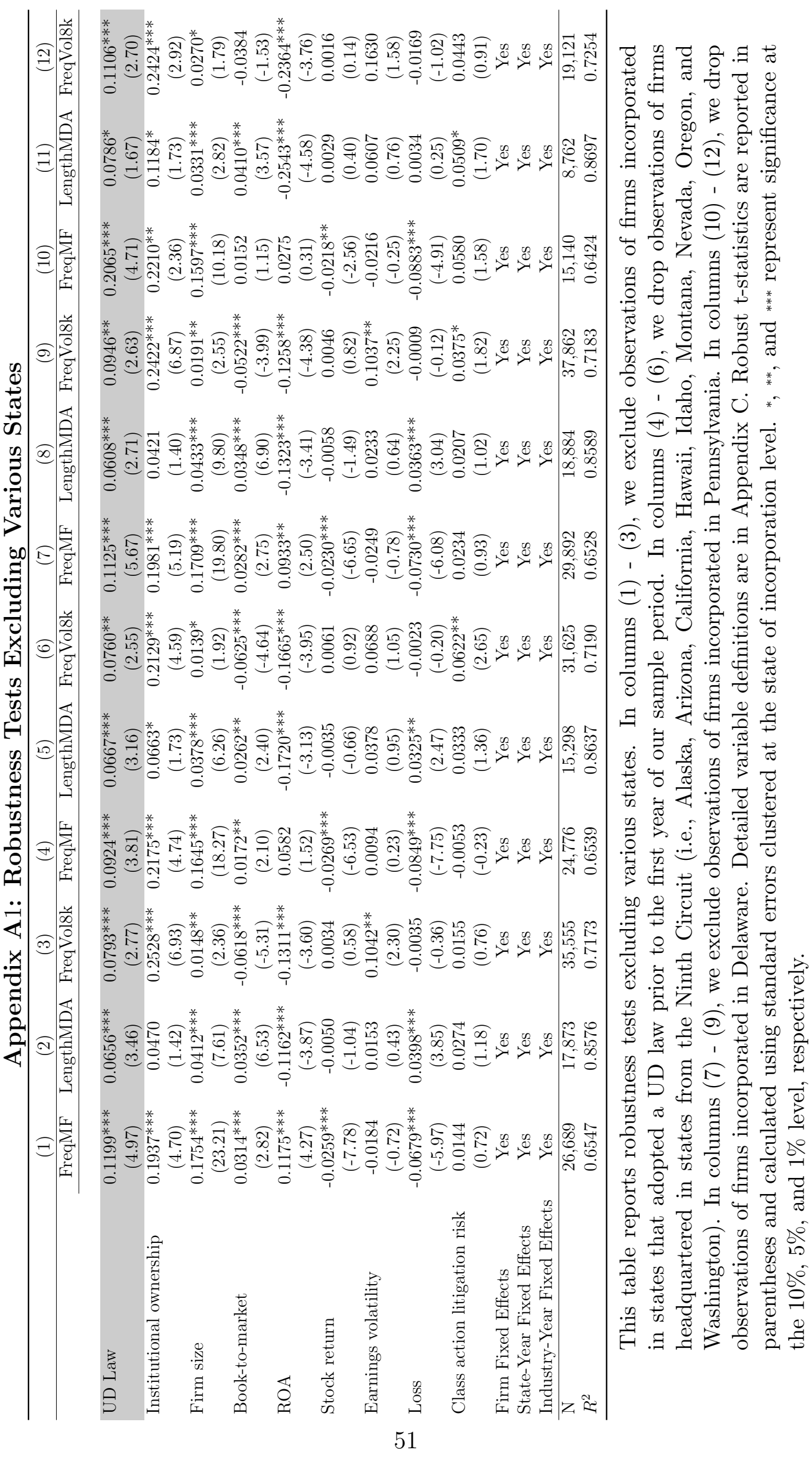

This article is protected by copyright. All rights reserved. 


\section{Appendix A2: The Impact of UD Laws on the Frequency of Mandatory 8-Ks}

$(1)$

\section{FreqMan8k FreqMan8k FreqMan8k}

\begin{tabular}{|c|c|c|c|}
\hline UD Law & $\begin{array}{c}0.0413 \\
(1.46)\end{array}$ & $\begin{array}{c}0.0398 \\
(1.28)\end{array}$ & $\begin{array}{c}0.0391 \\
(1.26)\end{array}$ \\
\hline Institutional ownership & & & $\begin{array}{c}0.2740^{* * *} \\
(5.75)\end{array}$ \\
\hline Firm size & & & $\begin{array}{c}-0.0178^{* * *} \\
(-2.73)\end{array}$ \\
\hline Book-to-market & & & $\begin{array}{c}-0.0725^{* * *} \\
(-6.25)\end{array}$ \\
\hline $\mathrm{ROA}$ & & & $\begin{array}{c}-0.0860^{* * *} \\
(-3.08)\end{array}$ \\
\hline Stock return & & & $\begin{array}{c}0.0125^{*} \\
(1.97)\end{array}$ \\
\hline Earnings volatility & & & $\begin{array}{c}0.0280 \\
(0.49)\end{array}$ \\
\hline Loss & & & $\begin{array}{c}0.0034 \\
(0.39)\end{array}$ \\
\hline Class action litigation risk & & & $\begin{array}{c}-0.0125 \\
(-0.64)\end{array}$ \\
\hline Firm Fixed Effects & Yes & Yes & Yes \\
\hline State-Year Fixed Effects & Yes & Yes & Yes \\
\hline Industry-Year Fixed Effects & No & Yes & Yes \\
\hline $\mathrm{N}$ & 39,055 & 39,055 & 39,055 \\
\hline$R^{2}$ & 0.7278 & 0.7300 & 0.7310 \\
\hline
\end{tabular}

This table reports the impact of UD laws on the frequency of mandatory 8-K filings. Detailed variable definitions are in Appendix C. Robust t-statistics are reported in parentheses and calculated using standard errors clustered at the state of incorporation level. *, ${ }^{* *}$, and ${ }^{* * *}$ represent significance at the $10 \%, 5 \%$, and $1 \%$ level, respectively.

This article is protected by copyright. All rights reserved. 
仓ัن

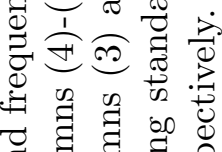

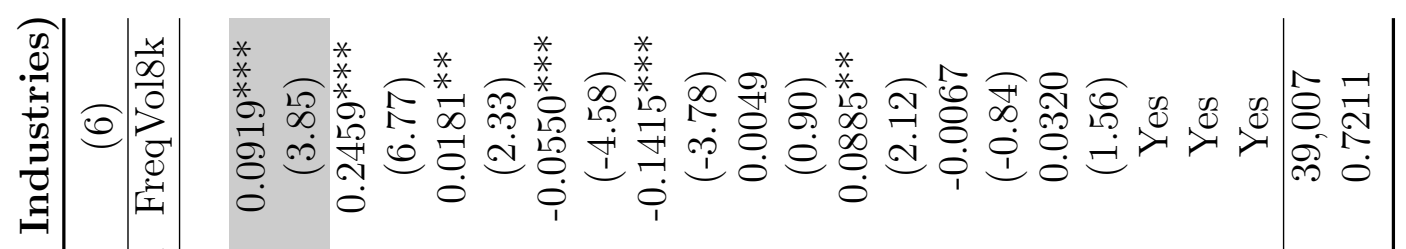
表

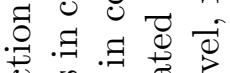

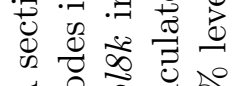

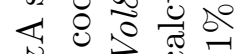

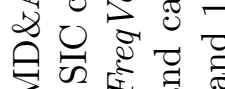

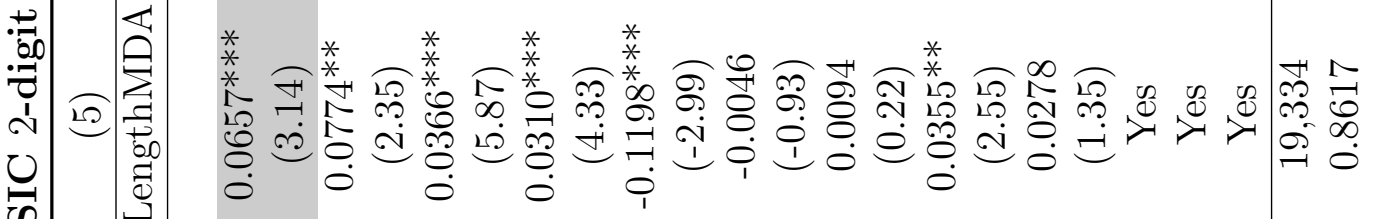

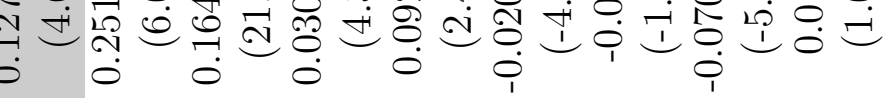

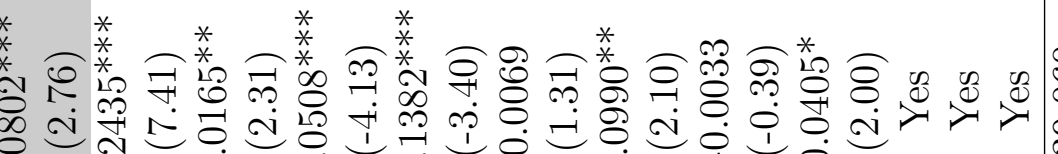

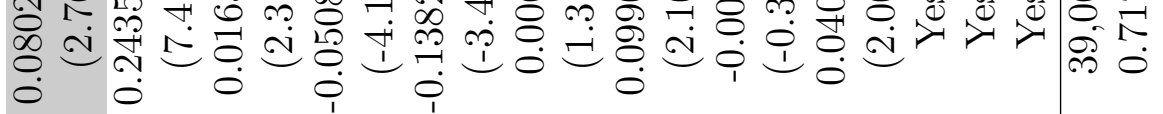

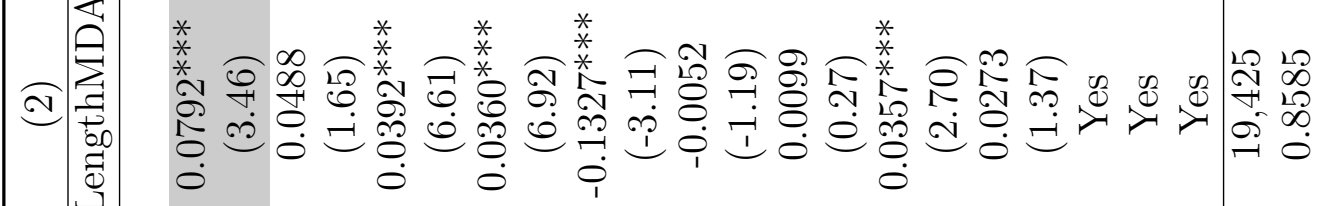

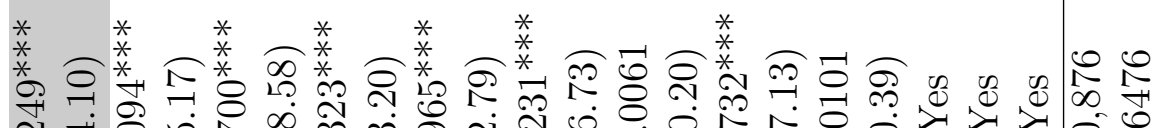

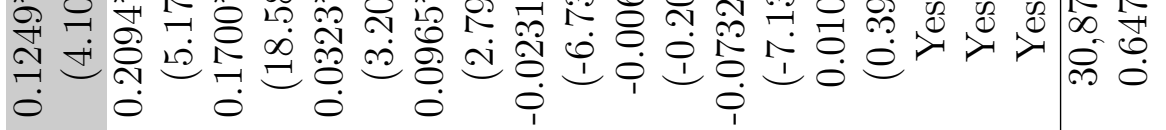
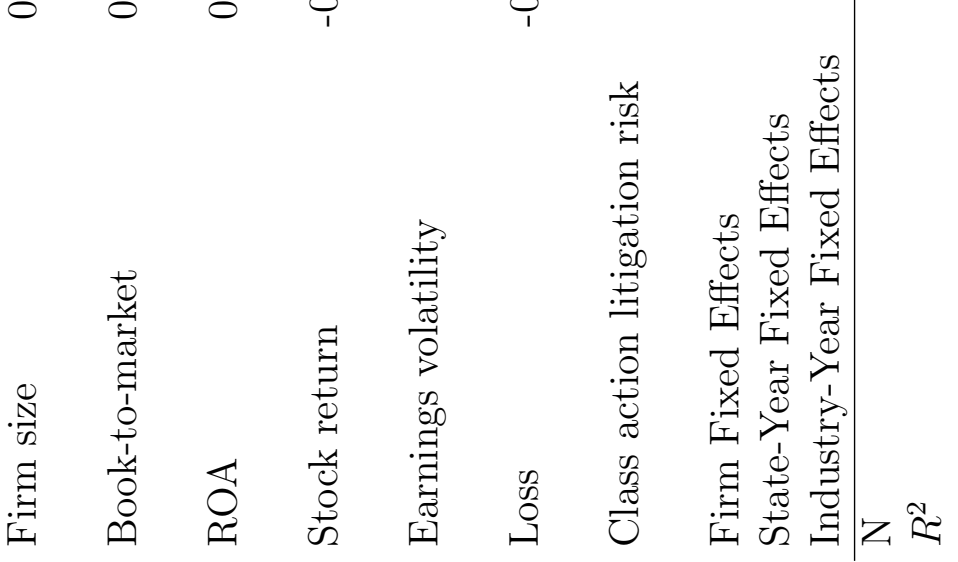


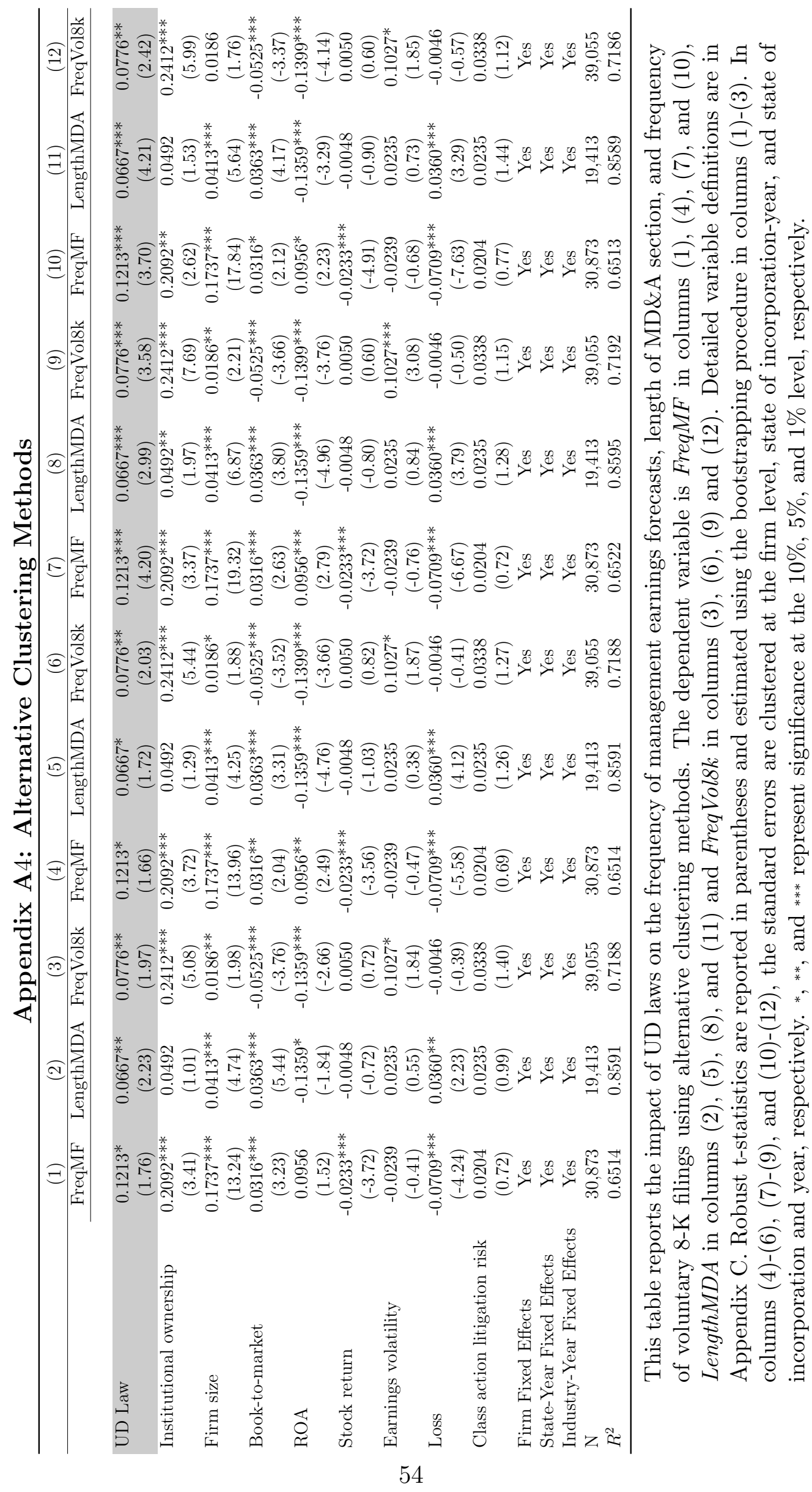

This article is protected by copyright. All rights reserved. 


\section{Appendix A5: Adoption of UD Laws and State-level Disclosure Environment}

\begin{tabular}{lc}
\hline & $(1)$ \\
\hline & UD Law \\
Institutional ownership & 10.7924 \\
Firm size & $(0.97)$ \\
& 1.0559 \\
Book-to-market & $(0.88)$ \\
& -2.0458 \\
ROA & $(-1.13)$ \\
& 0.3603 \\
Stock return & $(0.03)$ \\
Earnings volatility & 2.3004 \\
& $(1.58)$ \\
Loss & 3.3424 \\
& $(0.85)$ \\
Class action litigation risk & -1.4966 \\
& $(-0.35)$ \\
Pseudo- $R^{2}$ & 5.1259 \\
\hline
\end{tabular}

This table reports the endogeneity test regarding the state-level disclosure determinants for the adoption of UD laws. The independent variables are the average disclosure determinants within each state of incorporation level and year. The state mean of each variable is also included but not reported for brevity. Robust z-statistics are reported in parentheses and calculated using standard errors clustered at the state of incorporation level. *, ${ }^{* *}$, and ${ }^{* * *}$ represent significance at the $10 \%, 5 \%$, and $1 \%$ level, respectively. 


\section{Appendix B: Adoption of Universal Demand (UD) Laws}

\begin{tabular}{|c|c|c|}
\hline State & Year & Reference \\
\hline Georgia & 1989 & Georgia Code Ann. $\S 14-2-742$ \\
\hline Michigan & 1989 & Michigan Comp. Laws Ann. $\S 450.1493 a$ \\
\hline Florida & 1990 & Florida Stat. Ann. $§ 607.07401$ \\
\hline Wisconsin & 1991 & Wisconsin Stat. Ann. $§ 180.742$ \\
\hline Montana & 1992 & Montana Code Ann. $\S 35-1-543$ \\
\hline Virginia & 1992 & Virginia Code Ann. $\S 13.1-672.1 \mathrm{~B}$ \\
\hline Utah & 1992 & Utah Code Ann. $\S$ 16-10a-740(3) \\
\hline New Hampshire & 1993 & New Hampshire Rev. Stat. Ann. $§$ 293-A:7.42 \\
\hline Mississippi & 1993 & Mississippi Code Ann. $§ 79-4-7.42$ \\
\hline North Carolina & 1995 & North Carolina Gen. Stat. $§ 55-7-42$ \\
\hline Arizona & 1996 & Arizona Rev. Stat. Ann. $\S 10-742$ \\
\hline Nebraska & 1996 & Nebraska Rev. Stat. $\S 21-2072$ \\
\hline Connecticut & 1997 & Connecticut Gen. Stat. Ann. § 33-722 \\
\hline Maine & 1997 & Maine Rev. Stat. Ann. 13-C, $§ 753$ \\
\hline Pennsylvania & 1997 & Cuker v. Mikalauskas (547 Pennsylvania. 600, 692 A.2d 1042) \\
\hline Texas & 1997 & Texas Bus. Org. Code Ann. 607.07401 \\
\hline Wyoming & 1997 & Wyoming Stat. $\S 17-16-742$ \\
\hline Idaho & 1998 & Idaho Code $\S 30-1-742$ \\
\hline Hawaii & 2001 & Hawaii Rev. Stat. $\S 414-173$ \\
\hline Iowa & 2003 & Iowa Code Ann. $\S 490.742$ \\
\hline Massachusetts & 2004 & Massachusetts Gen. Laws Ann. Ch. 156D, § 7.42 \\
\hline Rhode Island & 2005 & Rhode Island Gen. Laws $§ 7-1.2-710(\mathrm{C})$ \\
\hline South Dakota & 2005 & South Dakota Codified Laws 47-1A-742 \\
\hline
\end{tabular}

This table lists the states that adopted universal demand (UD) laws and the corresponding years as in Appel [2016]. 


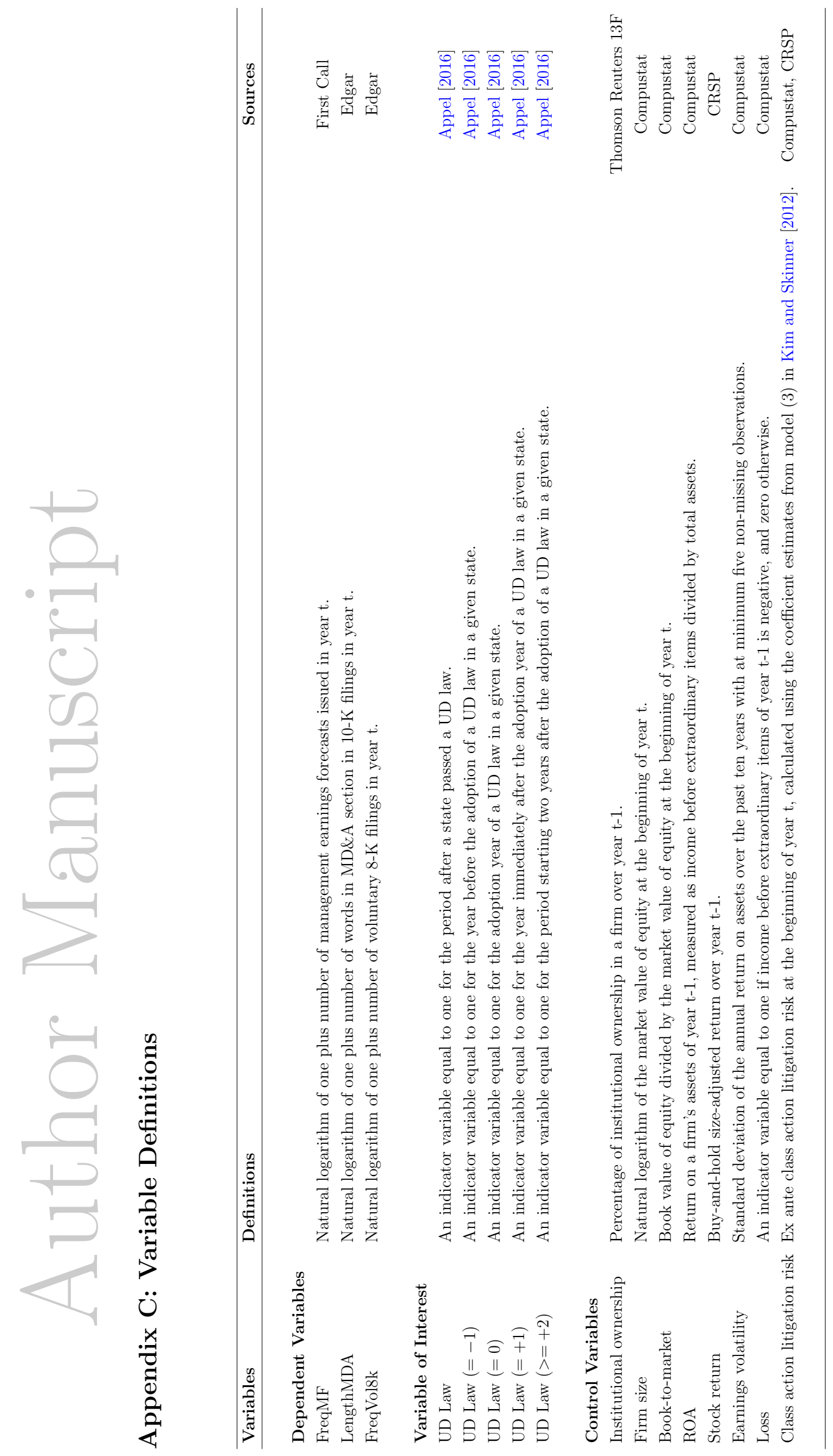

This article is protected by copyright. All rights reserved. 


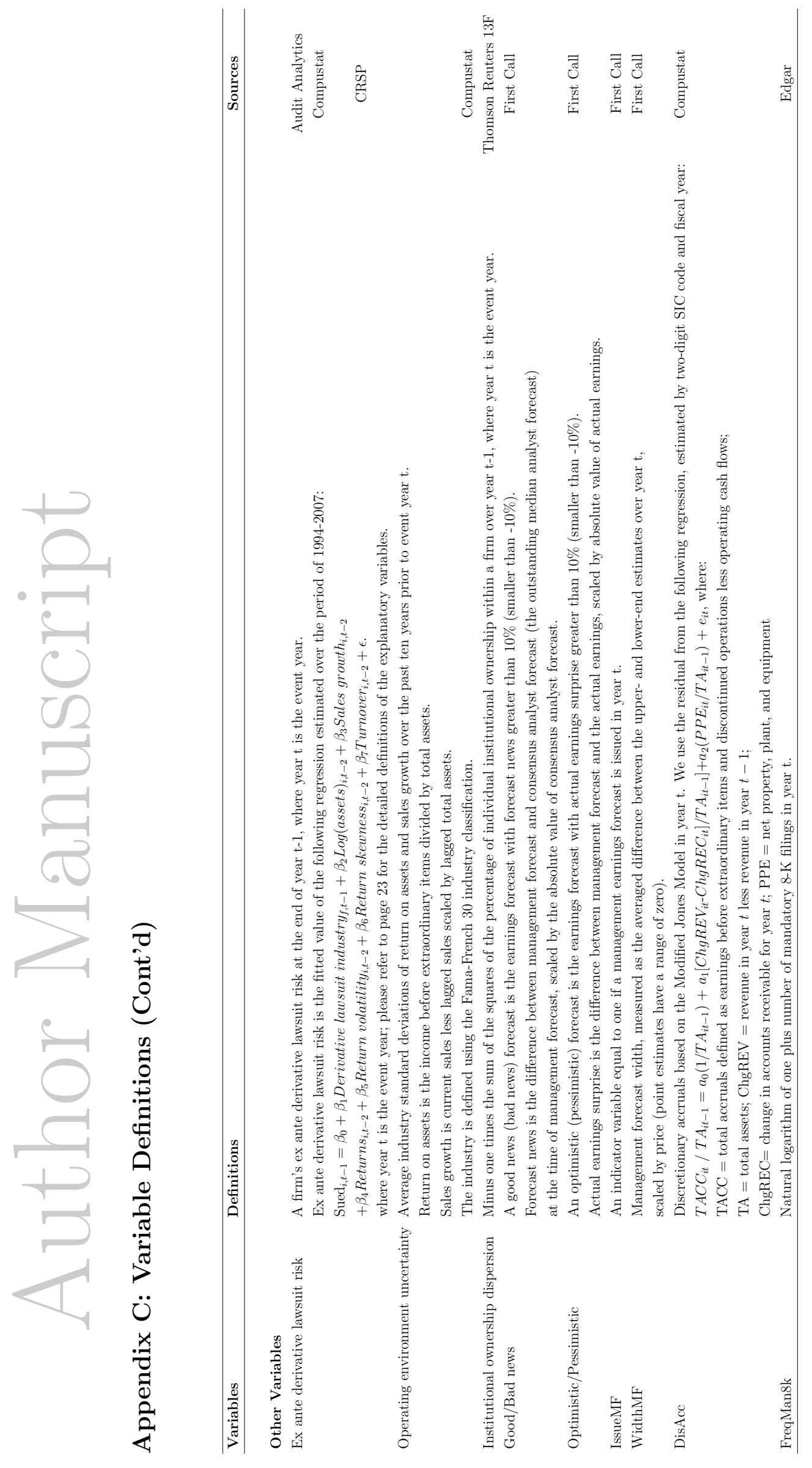

This article is protected by copyright. All rights reserved. 


\section{University Library}

\section{- M M N E R VA A gateway to Melbourne's research publications}

Minerva Access is the Institutional Repository of The University of Melbourne

Author/s:

Wang, R;Lou, Y;Bourveau, T

Title:

Shareholder Litigation and Corporate Disclosure: Evidence from Derivative Lawsuits

Date:

2018-06-01

Citation:

Wang, R., Lou, Y. \& Bourveau, T. (2018). Shareholder Litigation and Corporate Disclosure: Evidence from Derivative Lawsuits. Journal of Accounting Research, 56 (3), pp.797-842. https://doi.org/10.1111/1475-679X.12191.

Persistent Link:

http://hdl.handle.net/11343/283433 